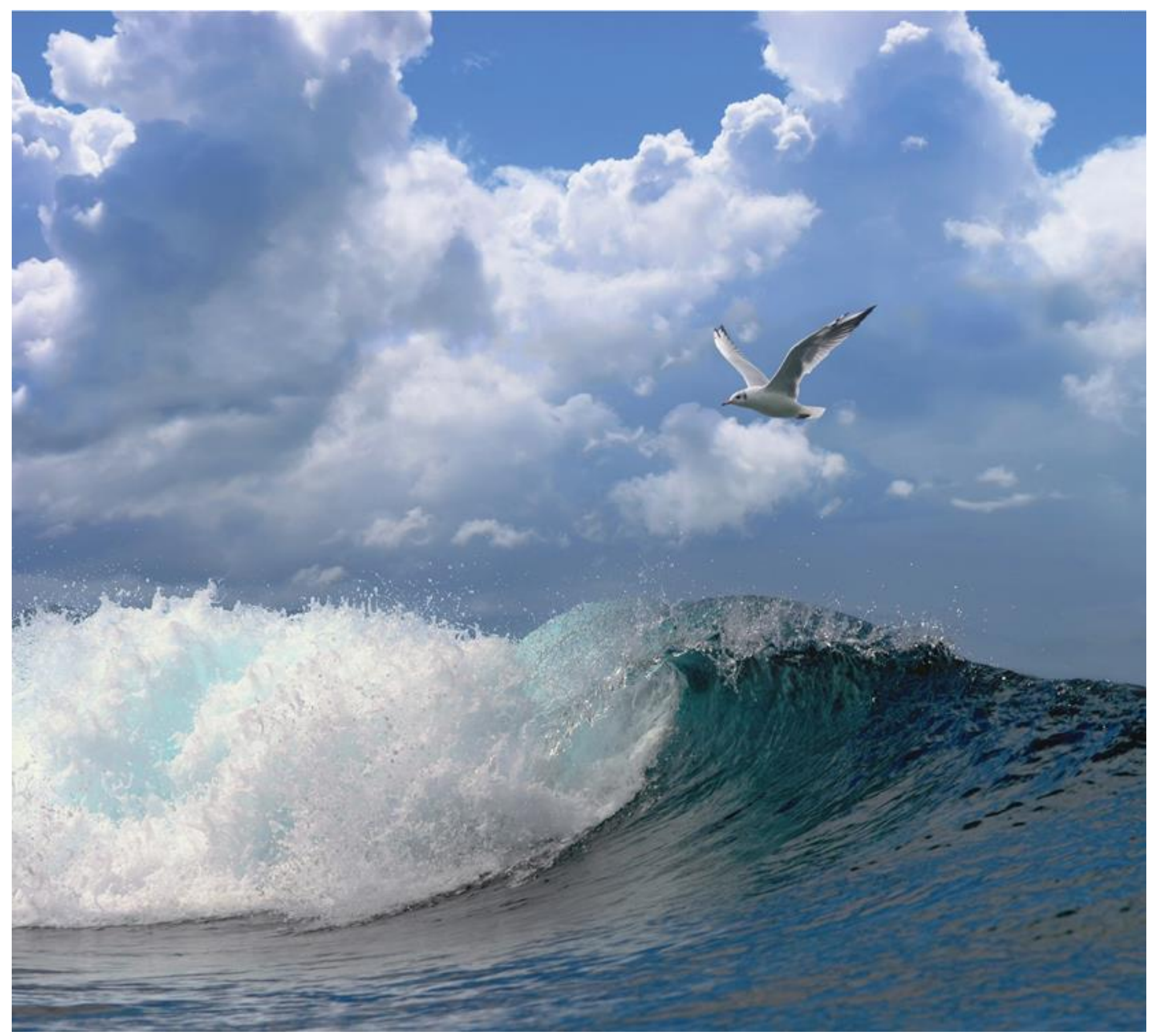

\title{
Cruiserapport scheepstellingen van zeevogels op het Friese Front en op de Bruine Bank, 2017
}




\section{Cruiserapport scheepstellingen van zeevogels op het Friese Front en op de Bruine Bank, 2017}

Auteurs: $\quad$ SCV Geelhoed, S Lagerveld, MF Leopold \& JP Verdaat

Publicatiedatum: 3 mei 2018

Dit onderzoek is uitgevoerd door Wageningen Marine Research in opdracht van en gefinancierd door het Ministerie van Economische Zaken, in het kader van het Beleidsondersteunend onderzoekthema 'Marien' (projectnummer BO-11-018.02-061)

Wageningen Marine Research Den Helder, 3 mei 2018

Wageningen Marine Research rapport C035/18 
SCV Geelhoed, S Lagerveld, MF Leopold \& JP Verdaat, Wageningen Marine Research Wageningen UR (University \& Research centre), Cruiserapport scheepstellingen van zeevogels op het Friese Front en op de Bruine Bank 2017, Wageningen Marine Research rapport C035/18. 38 blz.

Keywords: ESAS telling, grote jager, kleine mantelmeeuw, grote mantelmeeuw, zeevogel, alk, zeekoet, verspreiding, Bruine Bank, Friese Front

Opdrachtgever: Ministerie van Economische Zaken

T.a.v.: Anne-Marie Svoboda

Postbus 20401

2500 EK Den Haag

BAS code: BO-43-021.02-005

Dit rapport is gratis te downloaden van https://doi.org/10.18174/449007

Wageningen Marine Research verstrekt geen gedrukte exemplaren van rapporten.

Wageningen Marine Research Wageningen UR is ISO 9001:2008 gecertificeerd.

(C) 2017 Wageningen Marine Research Wageningen UR

Wageningen Marine Research, onderdeel van Stichting Wageningen Research KvK nr. 09098104,

IMARES BTW nr. NL 8113.83.696.B16.

Code BIC/SWIFT address: RABONL2U

IBAN code: NL 73 RABO 0373599285
De Directie van Wageningen Marine Research is niet aansprakelijk voor gevolgschade, noch voor schade welke voortvloeit uit toepassingen van de resultaten van werkzaamheden of andere gegevens verkregen van Wageningen Marine Research opdrachtgever vrijwaart Wageningen Marine Research van aanspraken van derden in verband met deze toepassing.

Dit rapport is vervaardigd op verzoek van de opdrachtgever hierboven aangegeven en is zijn eigendom. Niets uit dit rapport mag weergegeven en/of gepubliceerd worden, gefotokopieerd of op enige andere manier gebruikt worden zonder schriftelijke toestemming van de opdrachtgever. 


\section{Inhoud}

$\begin{array}{lr}\text { Samenvatting } & 4\end{array}$

$\begin{array}{llr}1 & \text { Inleiding } & 5\end{array}$

2 Kennisvraag $\quad 6$

3 Methoden $\quad 7$

$\begin{array}{lll}3.1 & \text { Studiegebied en survey design } & 7\end{array}$

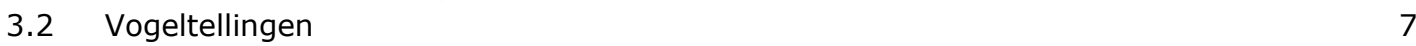

4 Resultaten $\quad 9$

$\begin{array}{llr}4.1 & \text { Surveyverslag } & 9\end{array}$

4.2 Waarnemingsomstandigheden $\quad 9$

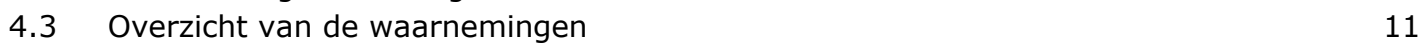

4.4 Soortbesprekingen $\quad 11$

4.4.1 Noordse Stormvogel 11

$\begin{array}{lll}4.4 .2 & \text { Jan-van-Gent } & 13\end{array}$

4.4.3 Zwarte Zee-eend $\quad 15$

$\begin{array}{lll}4.4 .4 & \text { Grote Jager } & 17\end{array}$

4.4.5 Kleine Mantelmeeuw $\quad 18$

$\begin{array}{lll}\text { 4.4.6 Grote Mantelmeeuw } & 20\end{array}$

$\begin{array}{lll}4.4 .7 & \text { Drieteenmeeuw } & 22\end{array}$

$\begin{array}{lll}4.4 .8 & \text { Alk } & 24\end{array}$

4.4.9 Zeekoet $\quad 26$

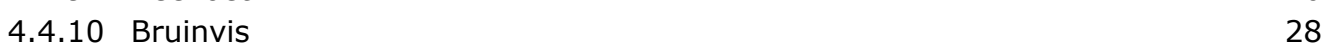

$5 \quad$ Conclusies en aanbevelingen $\quad 31$

$6 \quad$ Literatuur $\quad 32$

$\begin{array}{llr}7 & \text { Kwaliteitsborging } & 33\end{array}$

$\begin{array}{lr}\text { Verantwoording } & 34\end{array}$

Bijlagen Aantallen waargenomen vogels en zeezoogdieren 35 


\section{Samenvatting}

Het Friese Front en de Bruine Bank zijn twee nieuwe Vogelrichtlijngebieden in de Noordzee. Het Friese Front is aangewezen voor de Zeekoet. De Bruine Bank wordt waarschijnlijk aangewezen voor Zeekoet en Alk. Om te bepalen of de instandhoudingsdoelstellingen voor deze soorten worden gehaald, moeten de aantallen van deze soorten gemonitord worden. Monitoring van zeevogels in het Nederlandse deel van de Noordzee vindt plaats met behulp van MWTL-vliegtuigtellingen. Alken en Zeekoeten kunnen vanuit de lucht echter lastig van elkaar te onderscheiden zijn. Vanaf schepen is de herkenning eenvoudiger.

Het onderhavige BO-project 'scheepstellingen zeevogels' dat in 2016-2018 loopt, heeft tot doel inzicht te geven in de aantallen van Alken en Zeekoeten in beide gebieden enerzijds, en anderzijds in de veranderingen in aantalsverhouding tussen beide soorten gedurende het jaar om de MWTLvliegtuigtellingen te calibreren.

In 2017 zijn drie succesvolle scheepssurveys uitgevoerd op het Friese Front (28 feb- 3 mrt, 23- 26 jul) en op de Bruine Bank (22-26 jan). Op de Bruine Bank werden in januari 9571 individuen van 30 verschillende vogelsoorten geteld. Grote Mantelmeeuw $(n=1797)$, Zeekoet $(n=1412)$, Aalscholver ( $n$ $=1204)$, meeuw spec $(n=1150)$. Jan-van-Gent $(n=902)$, Drieteenmeeuw $(n=771)$ en gans spec $(n=579)$ domineerden de telling. Daarnaast werden 153 individuen verdeeld over zes soorten zeezoogdieren (Witsnuitdolfijn, Bultrug, Bruinvis, Grijze Zeehond, Gewone Zeehond en zeehond spec) geregistreerd.

Tijdens de survey op het Friese Front in maart werden 763 individuen verdeeld over 16 verschillende vogelsoorten geteld. Zeekoet $(n=258)$, Drieteenmeeuw $(n=151)$, Alk $(n=105)$, Jan-van-Gent $(n=$ 59) en Kleine Mantelmeeuw ( $n=57$ ) waren de dominante soorten. Daarnaast werden 22 individuen verdeeld over twee soorten zeezoogdieren (Bruinvis, Gewone Zeehond) gezien.

In juli werden op het Friese Front 6491 individuen van 19 verschillende vogelsoorten geteld. Zeekoet $(n=4725)$, Jan-van-Gent $(n=588)$ en Drieteenmeeuw $(n=530)$ domineerden de telling. Daarnaast werden 58 individuen verdeeld over drie soorten zeezoogdieren (Bruinvis, Grijze Zeehond en zeehond spec) geregistreerd.

Tijdens alle surveys behoorden Alken en Zeekoeten tot de talrijkste soorten. In juli werden de hoogste aantallen Zeekoeten op het Friese Front geteld, terwijl Alken hier ontbraken. De verhouding Alk:

Zeekoet was op de Bruine Bank in januari en op het Friese Front in maart respectievelijk 1: 3.2 en 1:

3.7

Behalve van alkachtigen werden aanvullende gegevens verzameld over de aantallen van potentieel kwalificerende N2000-soorten Grote Mantelmeeuw (met name jan-mrt) en Kleine Mantelmeeuw (met name jul). De aantallen van de potentieel kwalificerende N2000-soort Grote Jager waren tijdens alle 2017-surveys laag.

De resultaten van de surveys in 2016 zijn gepubliceerd in Geelhoed \& Leopold (2017). Dit rapport geeft een beknopt overzicht van de resultaten van de surveys in 2017. In 2018 worden de resultaten van alle surveys nader uitgewerkt en gepresenteerd in een eindrapportage. 


\section{Inleiding}

Het Friese Front en de Bruine Bank zijn twee nieuwe Vogelrichtlijngebieden in de Noordzee. Het Friese Front is definitief aangewezen voor de Zeekoet. De Bruine Bank wordt waarschijnlijk aangewezen voor Zeekoet en Alk. Om te bepalen of de instandhoudingsdoelstellingen voor deze soorten worden gehaald, moeten deze soorten goed gemonitord worden. In deel 2 van de Mariene Strategie (het KRMMonitoringprogramma) zijn afspraken gemaakt over de monitoring van zeevogels. Het voorkomen van zeevogels in het Nederlandse deel van de Noordzee wordt gemonitord met behulp van MWTLvliegtuigtellingen.

Alken en Zeekoeten lijken sterk op elkaar. Er bestaat nog onzekerheid over de mogelijkheid om beide soorten op de MWTL-vlieghoogte van elkaar te onderscheiden. Vanaf een schip zijn deze beide alkachtigen goed van elkaar te onderscheiden. Om de bruikbaarheid van de MWTL-tellingen voor het monitoren van beide soorten te vergroten is een antwoord op de volgende vraag noodzakelijk. Kan er op basis van scheepstellingen een 'standaard' aantalsverdeling tussen Alk en Zeekoet in een bepaalde periode vastgesteld worden, waarmee de onzekerheid in de met vliegtuig getelde aantallen kan worden verkleind? Eerder is door de voorloper van Wageningen Marine Research, IMARES, een 'parallelle scheepstelling' uitgevoerd om te bezien of daarmee tot 'ijking' van de vliegtuigtellingen gekomen kon worden. Dit was op basis van die tellingen niet mogelijk. Meerdere jaren van dergelijke scheepstellingen bieden mogelijk wel uitkomst. In het BO-project 'scheepstellingen zeevogels' zullen dergelijke scheepssurveys in de jaren 2016-2018 uitgevoerd worden.

Het onderzoek heeft tot doel inzicht te geven in enerzijds de aantallen van Alken en Zeekoeten in de gebieden Friese Front en Bruine Bank, en anderzijds in de veranderingen in aantalsverhouding tussen beide soorten gedurende het jaar. Deze gegevens zullen gebruikt worden om de MWTL-vliegtuigtellingen te kalibreren.

De scheepstellingen zijn primair gericht op Alken en Zeekoeten, maar alle soorten worden geteld, waaronder potentieel kwalificerende N2000-soorten, Grote Jager, Kleine Mantelmeeuw en Grote Mantelmeeuw. Voor deze soorten zijn op dit moment geen tellingen van voldoende kwaliteit beschikbaar om te bepalen of ze kwalificeren als selectiesoort of als begrenzingssoort voor (een van) beide N-2000 gebieden Friese Front of Bruine Bank (Leopold \& van der Wal 2015, Leopold et al. 2015). 


\section{Kennisvraag}

In het BO-project scheepstellingen zeevogels worden antwoorden gezocht op een drietal vragen:

1) Wat is de aantalsverdeling tussen Alk en Zeekoet in twee gebieden in verschillende perioden van het jaar teneinde resultaten van MWTL-vliegtuigtellingen te corrigeren/?

2) Welke aantallen Alken en Zeekoeten komen voor op het Friese Front en op de Bruine Bank?

3) Welke aantallen Kleine Mantelmeeuwen, Grote Mantelmeeuwen en Grote Jagers komen voor op het Friese Front en op de Bruine Bank? 


\section{Methoden}

\subsection{Studiegebied en survey design}

De surveys werden uitgevoerd in twee gebieden: het Friese Front en de Bruine Bank. Het Friese Front ligt ten noordnoordwesten van de westelijke Waddeneilanden. De Bruine Bank ligt aan de westkant van het Nederlands Continentaal Plat, ter hoogte van de Hollandse kust (figuur 1).

De surveys werden uitgevoerd op vooraf vastgestelde transecten. De transecten sluiten zo veel mogelijk aan bij eerder getelde transecten. De lengtes van de transecten waren afgestemd op haalbare afstanden gegeven de daglengtes, en windkracht en windrichting tijdens de wintersurveys.

Voor het Friese Front zijn de transecten geteld die tijdens eerdere surveys in 2009 zijn gedaan (Leopold et al. 2009). De ligging van de oostelijke transecten is licht aangepast om de surveytijd in de scheepvaartroutes te beperken. In maart zijn de transecten op het Friese Front aangepast in verband met het voorspelde slechte weer en de onmogelijkheid om de survey te verschuiven.

De Bruine Bank survey vond plaats in MCC-gebied 9 zoals door Van Bemmelen et al. (2012) gedefinieerd. Zij bestempelden MCC-gebied 9 als minimum kerngebied met hoge vogeldichtheden voor een Vogelrichtlijn- of Natura 2000-gebied. Naast deze inhoudelijke reden is het gebied als surveygebied gekozen om praktische redenen; binnen de beschikbare tijd was een groter gebied niet goed te onderzoeken. De transecten volgen het zigzagpatroon dat in 2014 is gebruikt (Geelhoed et al. 2014). Daarnaast zijn afhankelijk van de omstandigheden oost-westraaien geteld. Een set bleef binnen de contouren van het MCC-9 gebied, de transecten van de andere set liepen door tot de kustzone.

\section{MCC criterium}

Om vast te stellen of een gebied belangrijk is voor vogels zijn de Ramsar criteria ontwikkeld. Ramsar criterium 5 houdt in dat een gebied van internationaal belang is als er geregeld meer dan 20.000 vogels aanwezig zijn. Criterium 6 houdt in dat er geregeld $1 \%$ van de biogeografische populatie van een soort in het gebied aanwezig is In de Ramsar criteria is niet opgenomen hoe groot een gebied moet zijn waarin $1 \%$ van de biogeografische vogelpopulatie voorkomt. Daarom hebben Skov et al. (2007) het Marine Classification Criterion (MCC) ontwikkeld, dat stelt dat de dichtheid van een vogelsoort binnen een belangrijk offshore vogelgebied $4 x$ hoger moet zijn dan de gemiddelde dichtheid van die soort in de omringende regionale zee. Aantalscriteria (zoals Ramsar criteria 5 en 6 ) kunnen vervolgens getoetst worden binnen op basis van MCC geselecteerde gebieden.

\subsection{Vogeltellingen}

Tellingen zijn verricht volgens het standaard ESAS protocol (Tasker et al. 1984). Alle vogels en zeezoogdieren binnen een transect-strook van $300 \mathrm{~m}$ breed werden geteld. Daarnaast werd ook het gedrag genoteerd, waarbij de definities en codes van Camphuysen \& Garthe (2004) werden gebruikt. Tellingen werden uitgevoerd door twee waarnemersteams, ieder vanuit een observatiebox bovenop de brug, vanaf minstens 10 meter boven de waterlijn. Er is aan beide kanten van het schip steeds één strook van 300 meter breed geteld, verdeeld in vier afstandsbanden: A (0-50m), B (50-100m), C (100$200 \mathrm{~m}$ ) en $D(200-300 \mathrm{~m})$, dwars op de gevaren lijn. Vliegende vogels werden tijdens snapshots op iedere gehele minuut geteld, tot 300 meter voor de boeg: de afstand die het schip in één minuut aflegt. Waarnemingen werden per 5 minuten samen genomen. De tellingen werden gedurende de daglichtperiode uitgevoerd. 


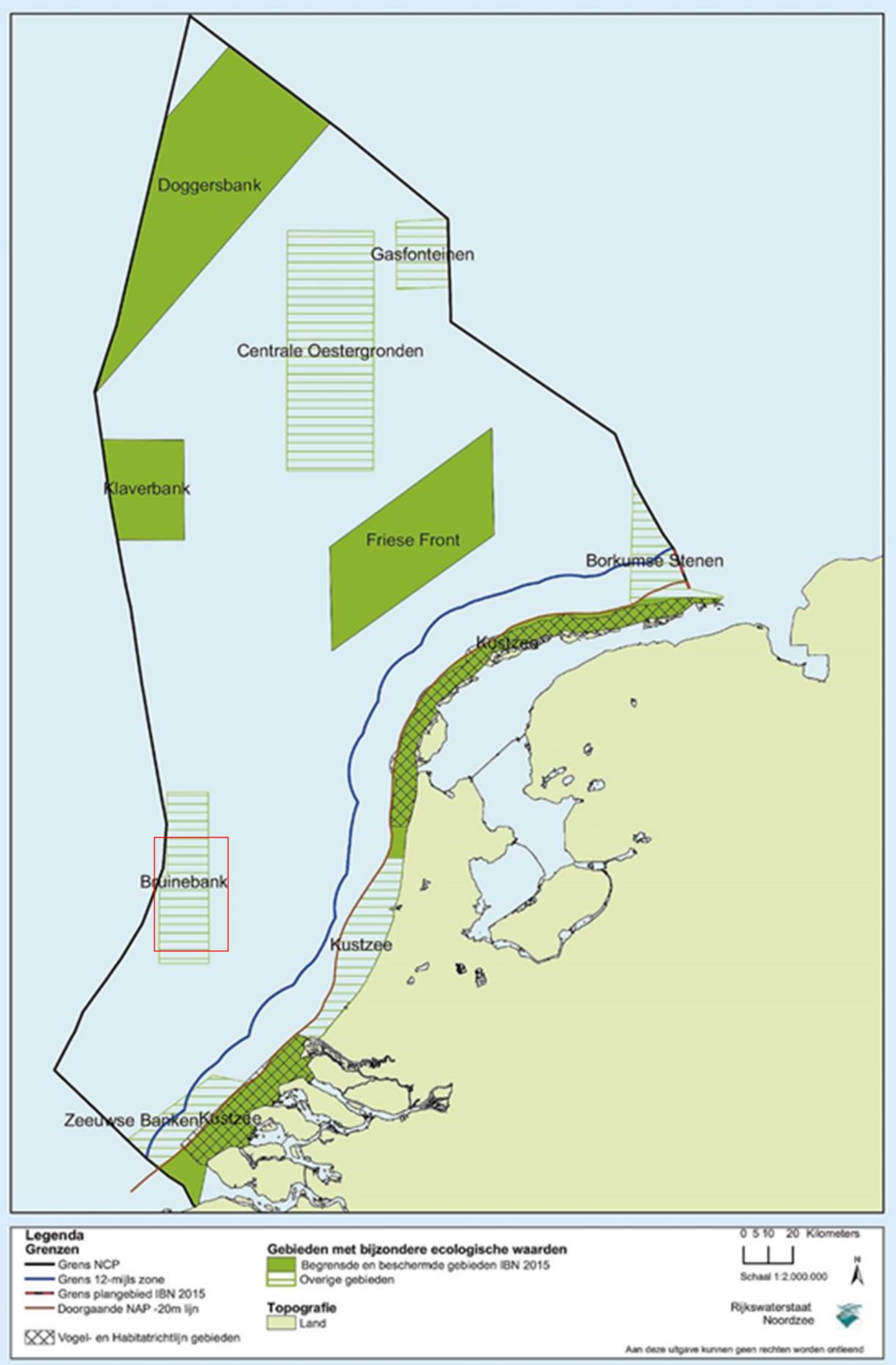

Figuur 1. Ligging van het Friese Front en van de Bruine Bank. Bron: Rijkswaterstaat. Het gearceerde gebied "Bruine Bank" is ingetekend volgens Lindeboom et al. (2005). De rode contour hier overheen geeft het door van Bemmelen et al. (2012) gedefinieerde MCC-gebied 9 weer. 


\section{Resultaten}

\subsection{Surveyverslag}

De eerste survey van 2017 vond plaats in de periode 22-26 januari vanaf de Vos Sweet. Waarnemers: Jos van de Berg, Steve Geelhoed, Mardik Leopold en Hans Verdaat. Zondagavond vertrek uit de haven van Beverwijk. Maandagochtend op het meest zuidoostelijke punt begonnen met de tellingen en zigzagtransecten naar het noorden geteld. 's Nachts stoomde het schip langzaam naar het zuiden om de volgende dag na zonsopkomst met tellen te beginnen in het meest zuidwestelijke transect van de Bruine Bank. Nadat de zigzag transecten geteld waren, werden oost-westraaien geteld. Donderdagmiddag ontscheping in Beverwijk.

De tweede survey vond plaats in de periode 28 februari - 3 maart vanaf de Vos Sweet. Waarnemers: Steve Geelhoed, Sander Lagerveld, Mardik Leopold en Hans Verdaat. De weersvoorspellingen waren slecht, maar de survey kon niet verschoven worden. De transecten aangepast om het gebied in twee dagen te kunnen tellen en zoveel mogelijk rugwind te hebben. Dinsdagavond vertrek uit de haven van Den Helder om 's ochtends na zonsopkomst met tellingen op het Friese Front te beginnen. De voorspelde stormachtige wind beperkte zich tot het gebied ten zuiden van het Friese Front. Vrijdagochtend ontscheping in Den Helder.

De derde survey vond in de periode 23 - 26 juli plaats vanaf de Dina Scout. Waarnemers: Jos van de Berg, Steve Geelhoed, Mardik Leopold en Hans Verdaat. Zondagavond vertrek uit de haven van Den Helder om maandagochtend na zonsopkomst met tellingen op het Friese Front te beginnen. Dankzij de lange daglichtperiode kon de vaartijd efficiënt gebruikt worden, zodat donderdagochtend ontscheping Den Helder kon plaatsvinden.

\subsection{Waarnemingsomstandigheden}

Tijdens de drie surveys zijn in totaal 1293 5-mintellingen uitgevoerd. In totaal is $2008.34 \mathrm{~km}$ geteld, hetgeen met een telstrook van twee maal 300 meter overeenkomt met $587.5 \mathrm{~km}^{2}$ (tabel 1). weergegeven waarnemingsinspanning is inclusief de getelde transecten buiten de potentiële N2000gebieden Bruine Bank en Friese Front. Zowel het aantal tellingen als de getelde oppervlakte zijn gedeeltelijk afhankelijk van de daglengte, en de waarnemingsomstandigheden.

Tabel 1. Waarnemingsinspanning per dag; weergegeven is het aantal 5-mintellingen, de getelde oppervlakte en de getelde afstand.

\begin{tabular}{|c|c|c|c|}
\hline Datum & 5-min telling & Oppervlak $\left(\mathrm{km}^{2}\right)$ & Afstand ( $\mathrm{km})$ \\
\hline \multicolumn{4}{|c|}{ Bruine Bank januari } \\
\hline 23-jan & 162 & 74.83 & 249.48 \\
\hline 24-jan & 161 & 74.32 & 247.71 \\
\hline 25-jan & 172 & 81.25 & 270.84 \\
\hline 26-jan & 14 & 5.91 & 19.72 \\
\hline Totaal & 517 & 236.31 & 787,71 \\
\hline \multicolumn{4}{|c|}{ Friese Front maart } \\
\hline $1-\mathrm{mrt}$ & 186 & 85.03 & 283.43 \\
\hline 2-mrt & 114 & 51.37 & 171.25 \\
\hline Totaal & 300 & 136.40 & 454.68 \\
\hline \multicolumn{4}{|c|}{ Friese Front juli } \\
\hline 24-jul & 216 & 97.88 & 326.33 \\
\hline 25-jul & 164 & 116.89 & 389.62 \\
\hline Totaal & 476 & 214.78 & 715.95 \\
\hline
\end{tabular}




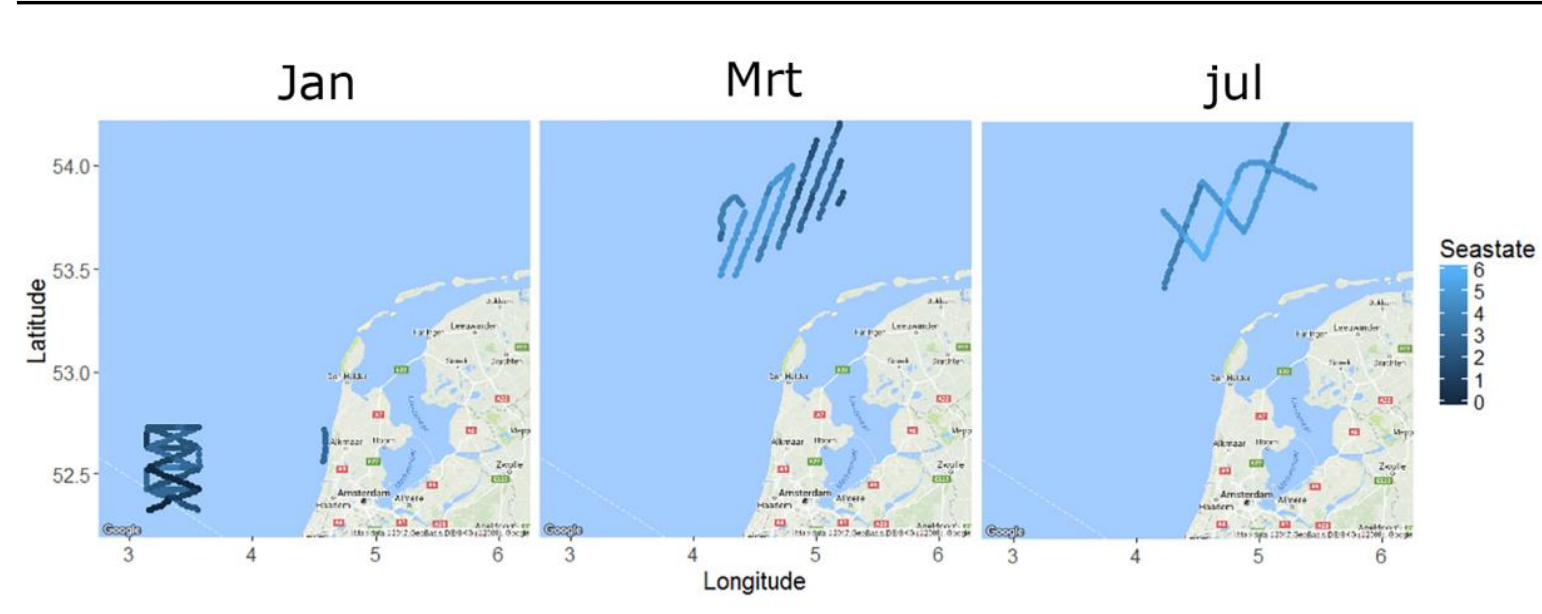

Figuur 3. Waarnemingsomstandigheden tijdens de surveys. Weergegeven is de zeestaat.

Tabel 2. Waarnemingsinspanning per zeestaat; weergegeven is het aantal 5-mintellingen, de getelde oppervlakte en de getelde afstand.

\begin{tabular}{|c|c|c|c|}
\hline Zeestaat & 5-min telling & Oppervlak $\left(\mathrm{km}^{2}\right)$ & Afstand (km) \\
\hline \multicolumn{4}{|c|}{ Bruine Bank januari } \\
\hline 1 & 65 & 29.70 & 98.99 \\
\hline 2 & 46 & 22.44 & 74.79 \\
\hline 3 & 171 & 78.79 & 262.64 \\
\hline 4 & 220 & 102.09 & 340.30 \\
\hline 5 & 7 & 3.29 & 10.98 \\
\hline \multirow[t]{2}{*}{6} & - & - & - \\
\hline & 509 & 236.31 & 787.71 \\
\hline \multicolumn{4}{|c|}{ Friese Front maart } \\
\hline 1 & - & - & - \\
\hline 2 & - & - & - \\
\hline 3 & - & - & - \\
\hline 4 & 110 & 50.48 & 168.26 \\
\hline 5 & 151 & 68.50 & 228.33 \\
\hline \multirow[t]{2}{*}{6} & 39 & 17.43 & 58.09 \\
\hline & 300 & 136.40 & 454.68 \\
\hline \multicolumn{4}{|c|}{ Friese Front juli } \\
\hline 1 & - & - & - \\
\hline 2 & 68 & 29.82 & 99.39 \\
\hline 3 & 142 & 65.29 & 217.65 \\
\hline 4 & 82 & 37.05 & 123.51 \\
\hline 5 & 184 & 82.62 & 275.40 \\
\hline \multirow[t]{2}{*}{6} & - & - & - \\
\hline & 476 & 214.78 & 715.95 \\
\hline
\end{tabular}

De waarnemingsomstandigheden varieerden per dag, maar waren over het algemeen goed genoeg om vogels te observeren. Tijdens de telling op de Bruine Bank waren de omstandigheden $46 \%$ van de tijd over het algemeen goed met een zeestaat $<4$ Beaufort. Dat wil zeggen kleine golfjes met niet meer dan enkele witte schuimkopjes, zodat alkachtigen relatief eenvoudig te zien zijn. Tijdens $43 \%$ van de tijd waren de omstandigheden matig met een zeestaat 4, waarbij veel golven schuimkoppen hadden (tabel 2).

De omstandigheden tijdens de tellingen op het Friese Front in maart en juli varieerden sterk. Tijdens de maarttellingen waren de omstandigheden matig tot slecht met een zeestaat van 4 Beaufort of meer. De helft van de tellingen werd uitgevoerd in zeestaat 5, waarbij wel zo veel mogelijk met de 
wind in de rug geteld werd. In juli waren de omstandigheden op het Friese Front goed tijdens 44\% van de 5-mintellingen. Tijdens de overige tellingen waren de omstandigheden met een zeestaat van minstens 4 Beaufort over het algemeen matig (tabel 2).

\subsection{Overzicht van de waarnemingen}

Een gedetailleerd overzicht van de waargenomen vogels, zeezoogdieren en overige opmerkelijke zaken tijdens de drie surveys is weergegeven in de bijlagen. Hierin worden ook de aantallen 5-min tellingen zonder waarnemingen en sporen van menselijk handelen (staand want, ballonnen) weergegeven. Nota bene: de getelde aantallen zijn niet hetzelfde als de aantallen vogels die totaal in het gebied aanwezig waren omdat het hier slechts een steekproef betreft.

Tijdens de eerste survey op de Bruine Bank in januari werden 9571 individuen van 30 verschillende vogelsoorten geteld. Grote Mantelmeeuw ( $n=1797)$, Zeekoet $(n=1412)$, Aalscholver $(n=1204)$, meeuw spec $(n=1150)$. Jan-van-Gent $(n=902)$, Drieteenmeeuw $(n=771)$ en gans spec $(n=579)$ domineerden de telling. Daarnaast werden 153 individuen verdeeld over zes soorten zeezoogdieren (Witsnuitdolfijn, Bultrug, Bruinvis, Grijze Zeehond, Gewone Zeehond en zeehond spec) geregistreerd. Tijdens de tweede survey op het Friese Front in maart werden 763 individuen verdeeld over 16 verschillende vogelsoorten geteld. Zeekoet $(n=258)$, Drieteenmeeuw $(n=151)$, Alk $(n=105)$, Janvan-Gent $(n=59)$ en Kleine Mantelmeeuw $(n=57)$ waren de dominante soorten. Daarnaast werden 22 individuen verdeeld over twee soorten zeezoogdieren (Bruinvis, Gewone Zeehond) gezien.

Tijdens de derde survey op het Friese Front in juli werden 6491 individuen van 19 verschillende vogelsoorten geteld. Zeekoet $(n=4725)$, Jan-van-Gent $(n=588)$ en Drieteenmeeuw $(n=530)$ domineerden de telling. Daarnaast werden 58 individuen verdeeld over drie soorten zeezoogdieren (Bruinvis, Grijze Zeehond en zeehond spec) geregistreerd.

\subsection{Soortbesprekingen}

\subsubsection{Noordse Stormvogel}

$\begin{array}{llll} & \text { jan-BB } & \text { mrt-FF } & \text { jul-FF } \\ \text { Aantal } & 310 & 16 & 207\end{array}$

Noordse Stormvogels werden tijdens alle surveys gezien. Op het Friese Front werd in maart een laag aantal gezien, terwijl er in juli grotere aantallen werden gezien. De hoogste aantallen werden in januari op de Bruine Bank vastgesteld. De verspreiding was onregelmatig. Dit werd deels veroorzaakt door de aanwezigheid van viskotters in een deel van het gebied. Een groot deel van de Noordse Stormvogels $(49 \%, n=533$ ) was geassocieerd met een actieve kotter; een kleiner percentage volgde het onderzoeksschip ( $1 \%, \mathrm{n}=533$ ). Zowel op het Friese Front als op de Bruine Bank lag het zwaartepunt van de verspreiding in het westelijk deel van de gebieden.

Op een zevental donkere vogels na, behoorden alle vogels waarvan de kleurfase vastgesteld kon worden ( $n=304)$, tot de lichte kleurfase. Opvallend genoeg werden twee donkere vogels in juli gezien. Deze kleurfase is zomers normaliter schaars op het NCP (Camphuysen \& Leopold, 1994). 


\section{jan_Bruine_Bank Noordse Stormvogel}

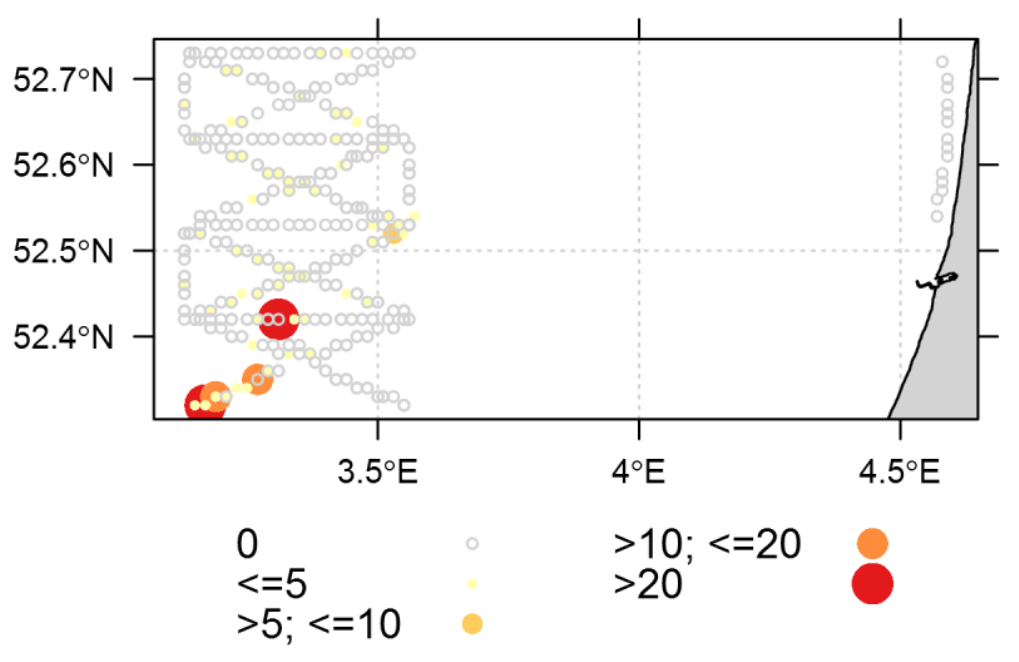

Figuur 4. Verspreiding van Noordse Stormvogel tijdens de survey op de Bruine Bank 23-26 januari 2017. Weergegeven zijn de gemiddelde aantallen per 5-mintelling.

\section{naart_Friese_Front Noordse Stormvoge}

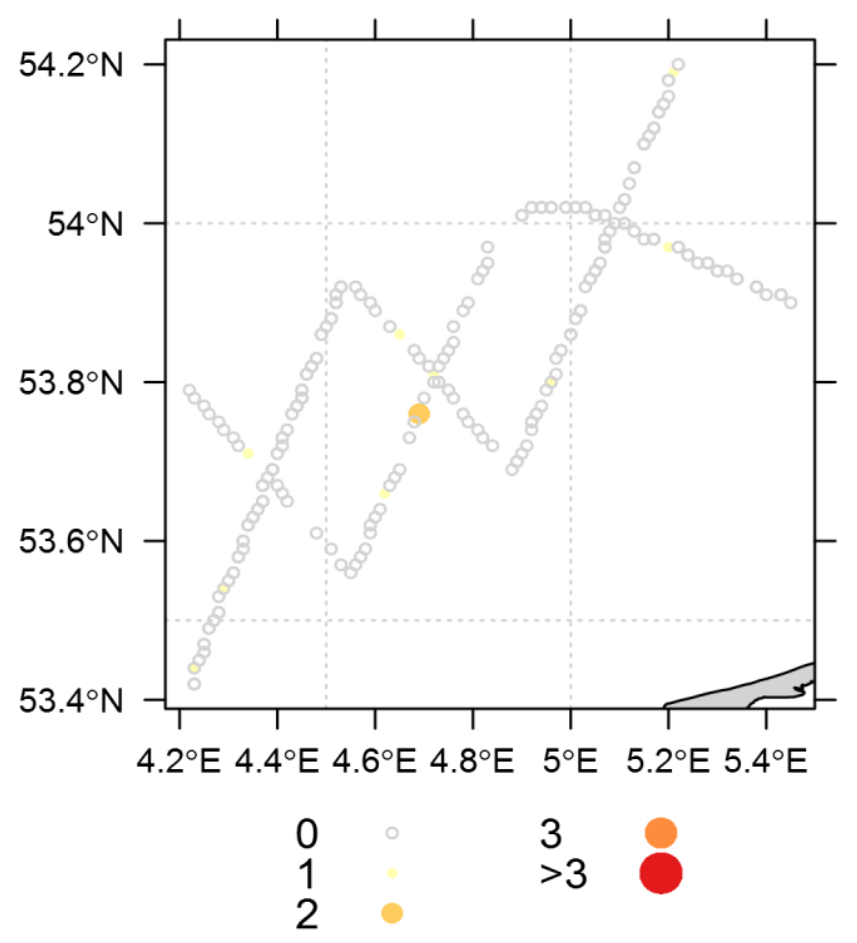

Figuur 5. Verspreiding van Noordse Stormvogel tijdens de survey op het Friese Front 1-2 maart 2017. Weergegeven zijn de gemiddelde aantallen per 5-mintelling. 


\section{juli_Friese_Front Noordse Stormvogel}

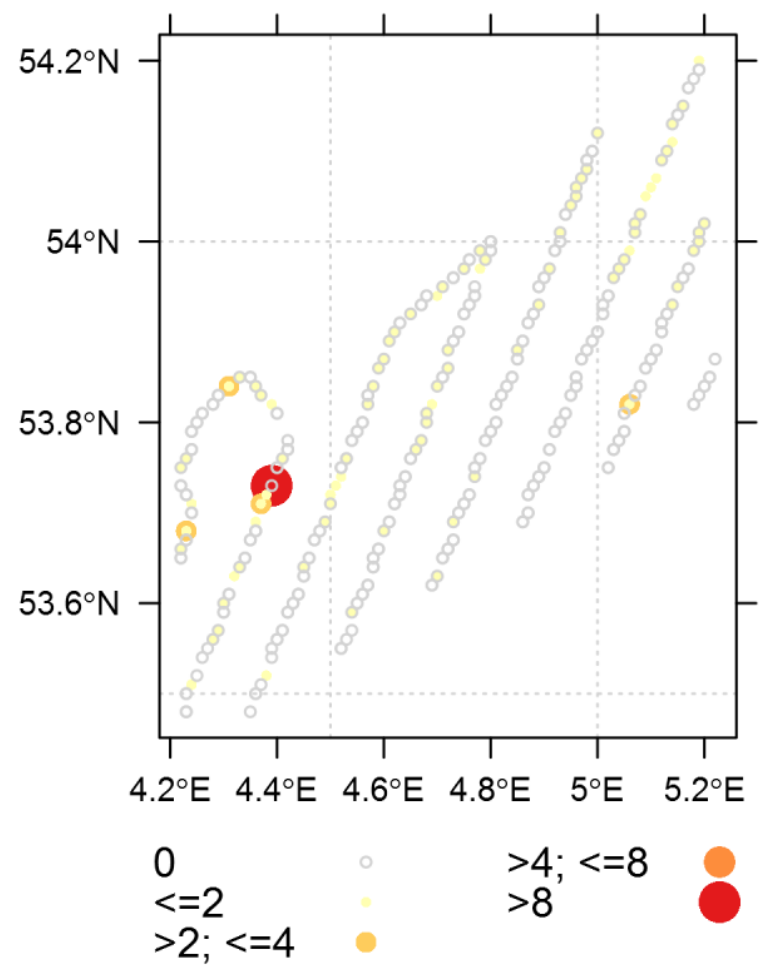

Figuur 6. Verspreiding van Noordse Stormvogel tijdens de survey op het Friese Front 24-25 juli 2017. Weergegeven zijn de gemiddelde aantallen per 5-mintelling.

\subsubsection{Jan-van-Gent}

$\begin{array}{llll} & \text { jan-BB } & \text { mrt-FF } & \text { jul-FF } \\ \text { Aantal } & 902 & 59 & 588\end{array}$

Jan-van-Genten werden tijdens alle surveys in redelijke aantallen gezien. Op de Bruine Bank, in januari werden de hoogste aantallen vastgesteld. Op het Friese Front waren de aantallen in maart laag, terwijl er in juli een tienvoud van de maartaantallen werd vastgesteld. De verspreiding in januari en juli was onregelmatig. Het beeld wordt grotendeels bepaald door associaties van grotere groepen met actieve viskotters $(49 \%, n=1549)$. Een laag aantal individuen was geassocieerd met het onderzoeksschip ( $1 \%, n=1549)$ of een gas productie platform $(<1 \%)$. Ondanks het relatief hoge aantal waarnemingen van zeezoogdieren en Jan-van-Genten in januari, werd slechts één associatie van een zoekende Jan-van-Gent en (vijf) bruinvissen vastgesteld. In alle telperioden waren adulte vogels in de meerderheid, minimaal $50 \%$ in juli $(n=220)$ en respectievelijk $92 \%$ en $98 \%$ in januari ( $n$ $=169)$ en maart $(n=m 59)$. 


\section{jan_Bruine_Bank Jan van Gent}

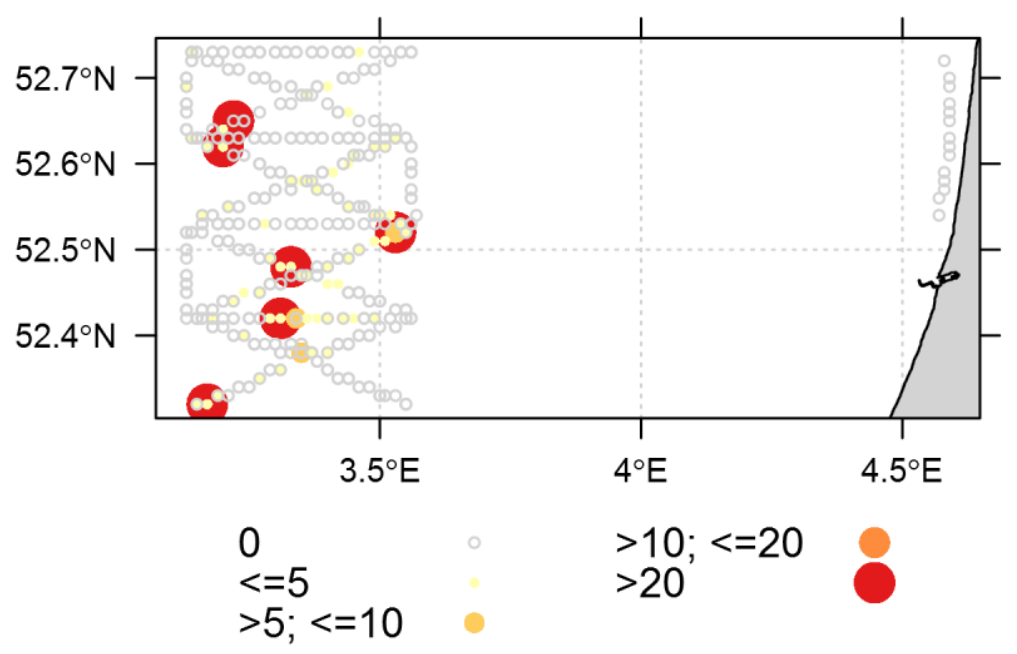

Figuur 7. Verspreiding van Jan-van-Gent tijdens de survey op de Bruine Bank 23-26 januari 2017. Weergegeven zijn de gemiddelde aantallen per 5-mintelling.

\section{maart_Friese_Front Jan van Gent}

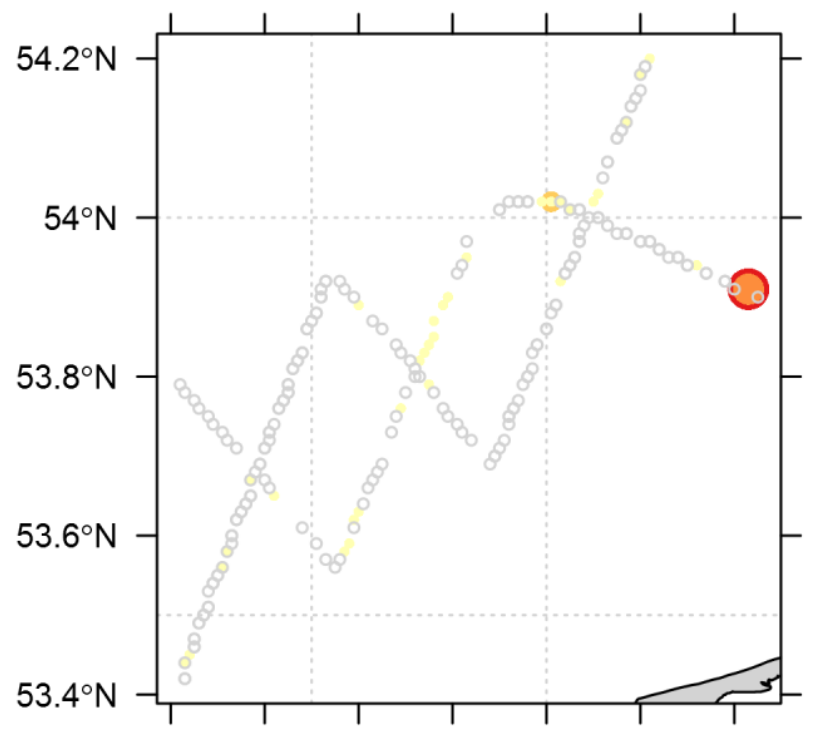

$4.2^{\circ} \mathrm{E} 4.4^{\circ} \mathrm{E} 4.6^{\circ} \mathrm{E} 4.8^{\circ} \mathrm{E} \quad 5^{\circ} \mathrm{E} 5.2^{\circ} \mathrm{E} 5.4^{\circ} \mathrm{E}$

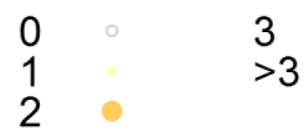

Figuur 8. Verspreiding van Jan-van-Gent tijdens de survey op het Friese Front 1-2 maart 2017. Weergegeven zijn de gemiddelde aantallen per 5-mintelling. 


\section{juli_Friese_Front Jan van Gent}

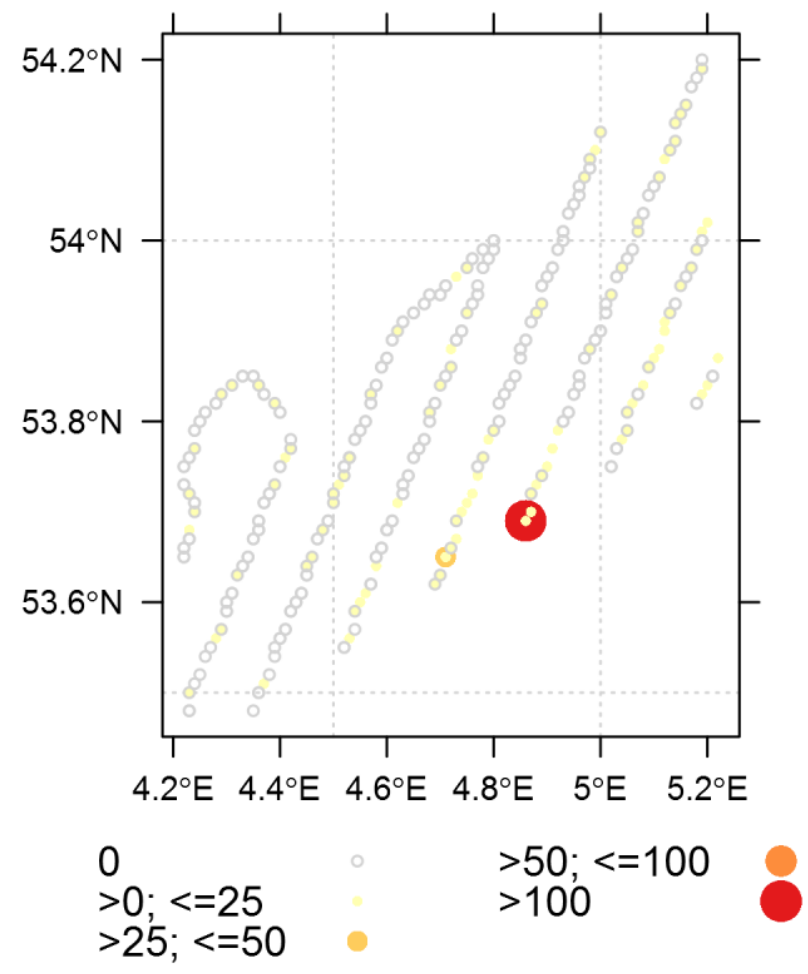

Figuur 9. Verspreiding van Jan-van-Gent tijdens de survey op het Friese Front 24-25 juli 2017. Weergegeven zijn de gemiddelde aantallen per 5-mintelling

\subsubsection{Zwarte Zee-eend}

$\begin{array}{llll} & \text { jan-BB } & \text { mrt-FF } & \text { jul-FF } \\ \text { Aantal } & 140 & 2 & 58\end{array}$

Zwarte Zee-eenden werden onregelmatig en in kleine aantallen gezien. In januari werden de hoogste aantallen gezien, maar ontbraken waarnemingen op de Bruine Bank. Alle vogels werden in de kustzone gezien. Tijdens de maartsurvey werden er slechts twee Zwarte Zee-eenden op het Friese Front gezien. In juli werden in dit gebied opmerkelijk veel vogels gezien. Alle waarnemingen betroffen langs vliegende groepjes. 


\section{jan_Bruine_Bank Zwarte Zee-eend}

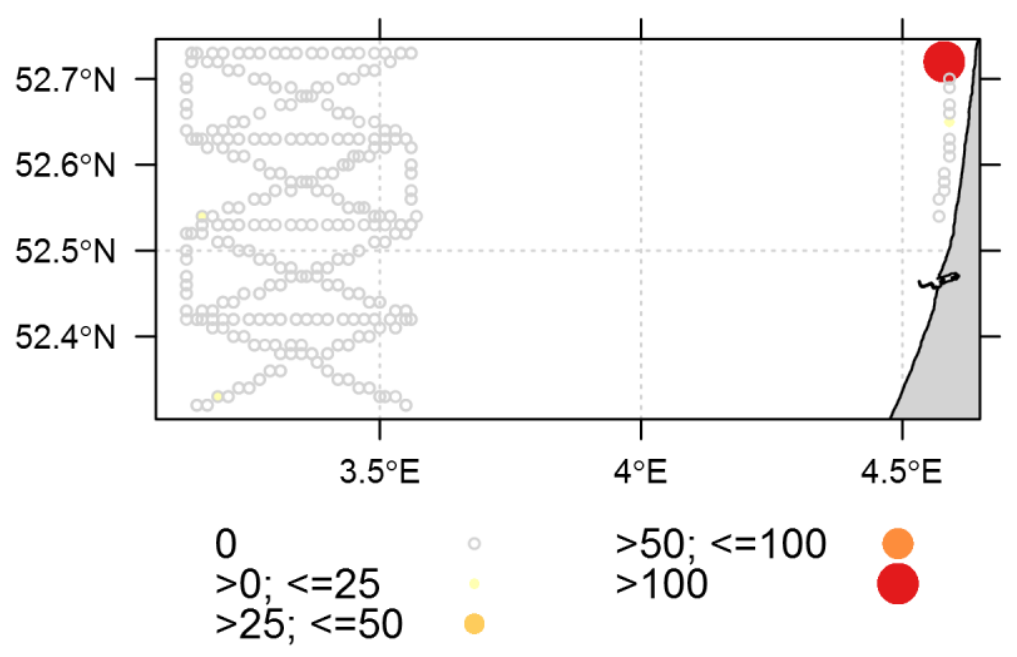

Figuur 10. Verspreiding van Zwarte Zee-eend tijdens de survey op de Bruine Bank 23-26 januari 2017. Weergegeven zijn de gemiddelde aantallen per 5-mintelling.

\section{maart_Friese_Front Zwarte Zee-eend}

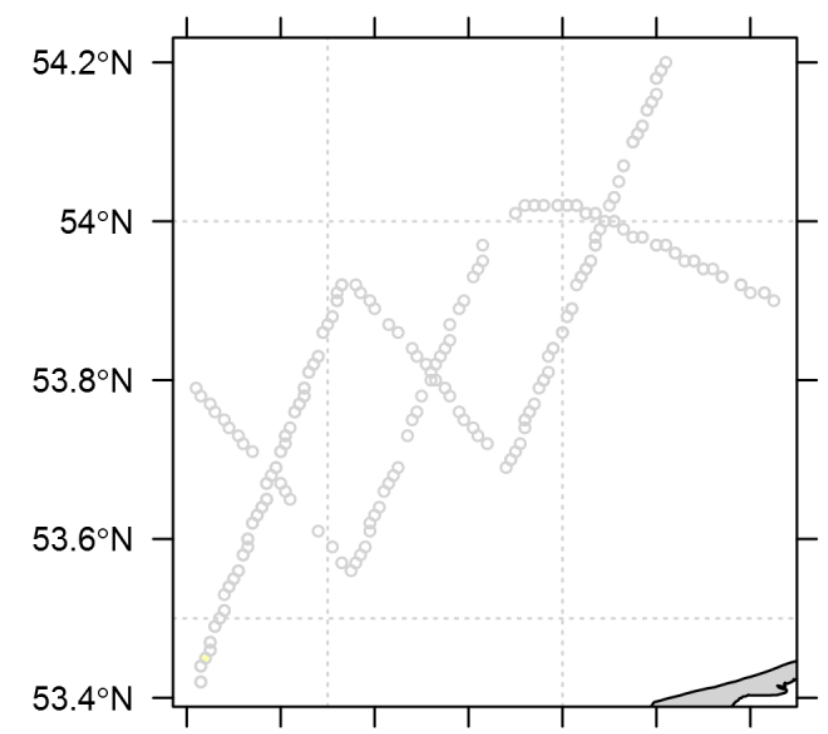

$4.2^{\circ} \mathrm{E} 4.4^{\circ} \mathrm{E} 4.6^{\circ} \mathrm{E} 4.8^{\circ} \mathrm{E} \quad 5^{\circ} \mathrm{E} \quad 5.2^{\circ} \mathrm{E} 5.4^{\circ} \mathrm{E}$

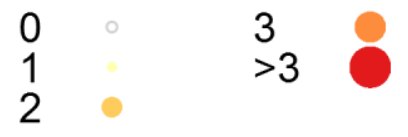

Figuur 11. Verspreiding van Zwarte Zee-eend tijdens de survey op het Friese Front 1-2 maart 2017. Weergegeven zijn de gemiddelde aantallen per 5-mintelling. 


\section{juli_Friese_Front Zwarte Zee-eend}

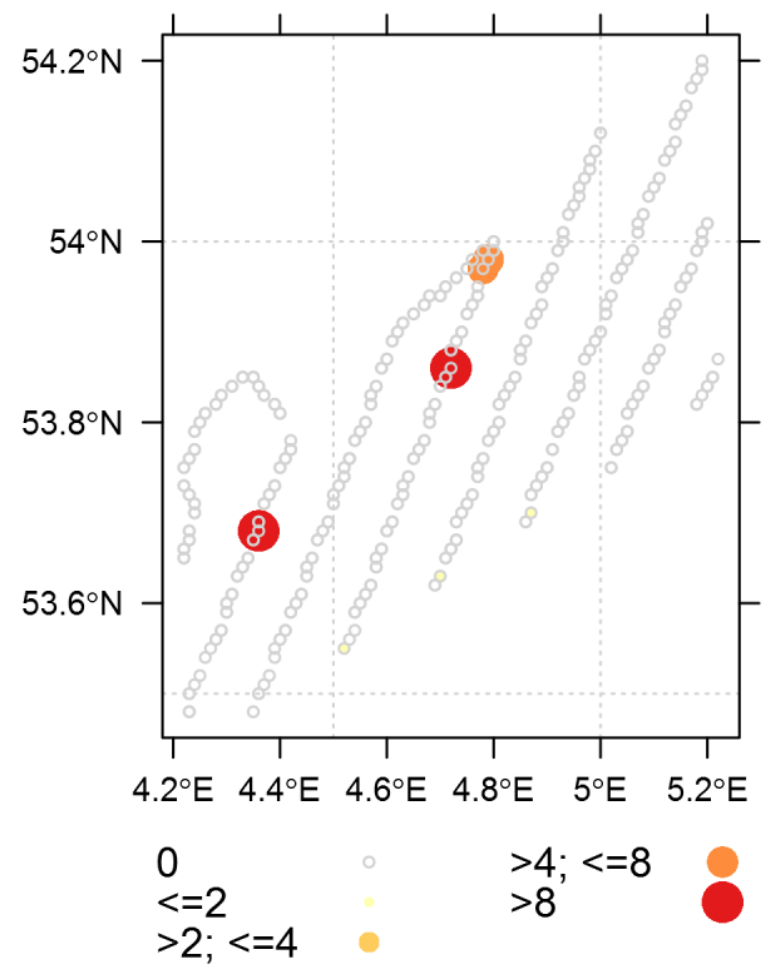

Figuur 12. Verspreiding van Zwarte Zee-eend tijdens de survey op het Friese Front 24-25 juli 2017. Weergegeven zijn de gemiddelde aantallen per 5-mintelling

\subsubsection{Grote Jager}

$\begin{array}{llll} & \text { jan-BB } & \text { mrt-FF } & \text { jul-FF } \\ \text { Aantal } & 6 & - & 3\end{array}$

Grote Jagers werden uitsluitend in januari en juli gezien. De aantallen waren beide perioden laag, Drie individuen waren geassocieerd met actieve viskotters. Ze joegen daarbij achter aanwezige meeuwen aan.

\section{jan_Bruine_Bank Grote Jager}

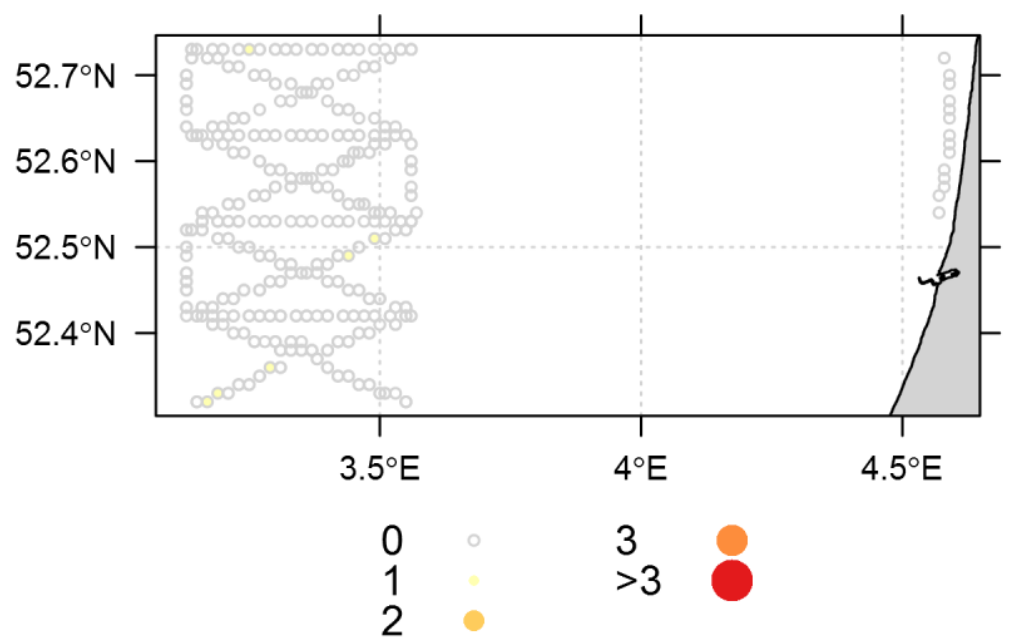


Figuur 13. Verspreiding van Grote Jager tijdens de survey op de Bruine Bank 23-26 januari 2017. Weergegeven zijn de gemiddelde aantallen per 5-mintelling.

\section{juli_Friese_Front Grote Jager}

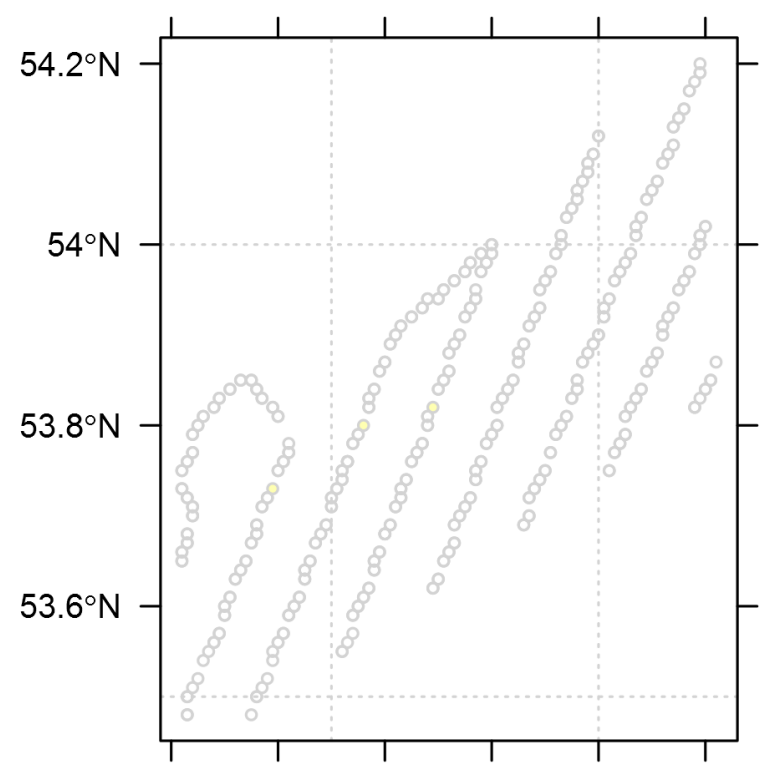

$4.2^{\circ} \mathrm{E} \quad 4.4^{\circ} \mathrm{E} \quad 4.6^{\circ} \mathrm{E} \quad 4.8^{\circ} \mathrm{E} \quad 5^{\circ} \mathrm{E} \quad 5.2^{\circ} \mathrm{E}$

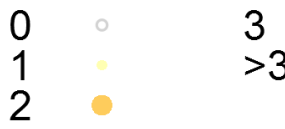

Figuur 14. Verspreiding van Grote Jager tijdens de survey op het Friese Front 24-25 juli 2017. Weergegeven zijn de gemiddelde aantallen per 5-mintelling.

\subsubsection{Kleine Mantelmeeuw}

$\begin{array}{llll} & \text { jan-BB } & \text { mrt-FF } & \text { jul-FF } \\ \text { Aantal } & 16 & 57 & 228\end{array}$

Kleine Mantelmeeuwen waren het zeldzaamst in januari en het talrijkst in juli. De meeste vogels werden in juli op het Friese Front gezien, veelal geassocieerd met vissende kotters. Ook in beide andere perioden werd de verspreiding grotendeels bepaald door de aanwezigheid van viskotters. Over de drie surveys was 73\% ( $n=331)$ geassocieerd met viskotters, en $3 \%(n=311)$ met het onderzoeksschip.

Het merendeel van de op leeftijd gebrachte vogels was volwassen ( $96 \%$ adult, $n=101$ ). In maart werd een onvolwassen vogel en in juli werden drie juvenielen genoteerd. 


\section{jan_Bruine_Bank Kleine Mantelmeeuw}

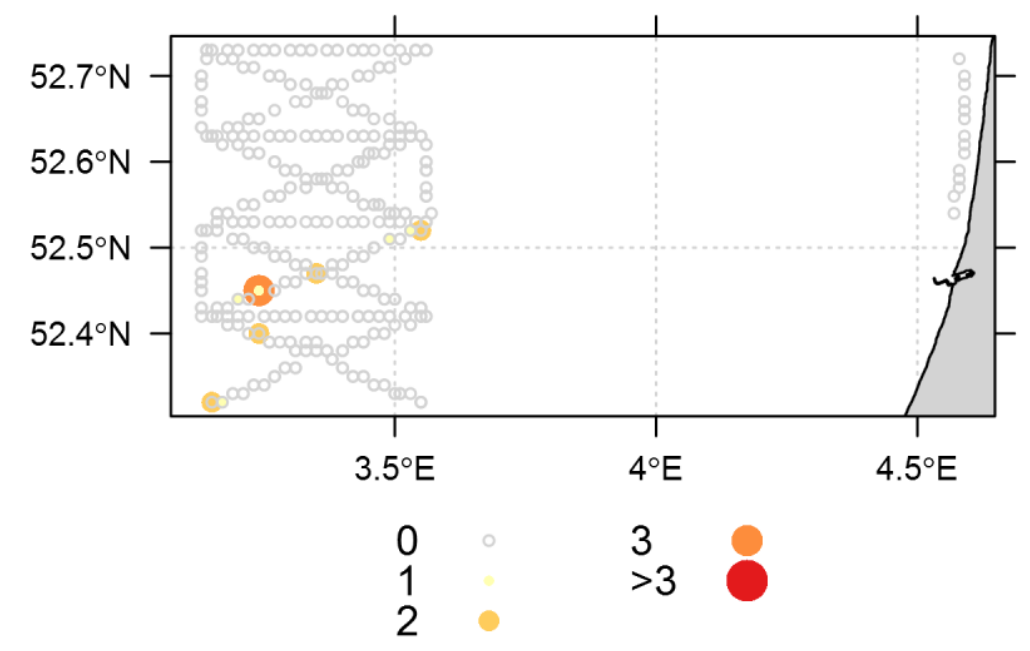

Figuur 15. Verspreiding van Kleine Mantelmeeuw tijdens de survey op de Bruine Bank 23-26 januari 2017. Weergegeven zijn de gemiddelde aantallen per 5-mintelling.

\section{naart_Friese_Front Kleine Mantelmeeuv}

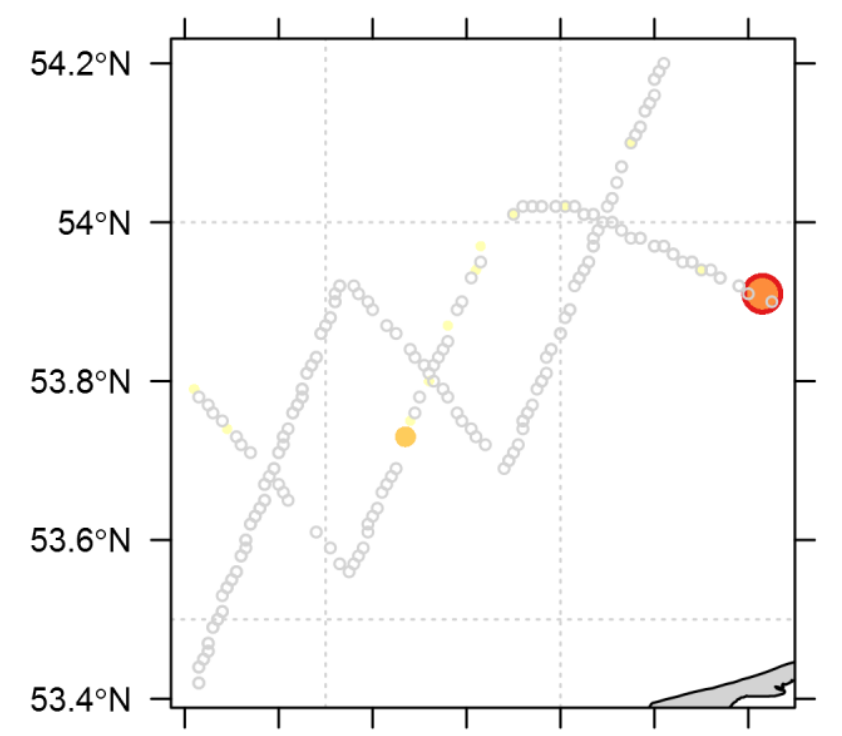

$4.2^{\circ} \mathrm{E} 4.4^{\circ} \mathrm{E} 4.6^{\circ} \mathrm{E} 4.8^{\circ} \mathrm{E} \quad 5^{\circ} \mathrm{E} \quad 5.2^{\circ} \mathrm{E} 5.4^{\circ} \mathrm{E}$

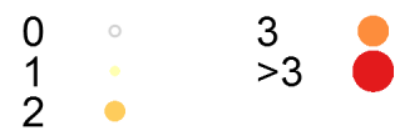

Figuur 16. Verspreiding van Kleine Mantelmeeuw tijdens de survey op het Friese Front 1-2 maart 2017. Weergegeven zijn de gemiddelde aantallen per 5-mintelling. 


\section{juli_Friese_Front Kleine Mantelmeeuw}

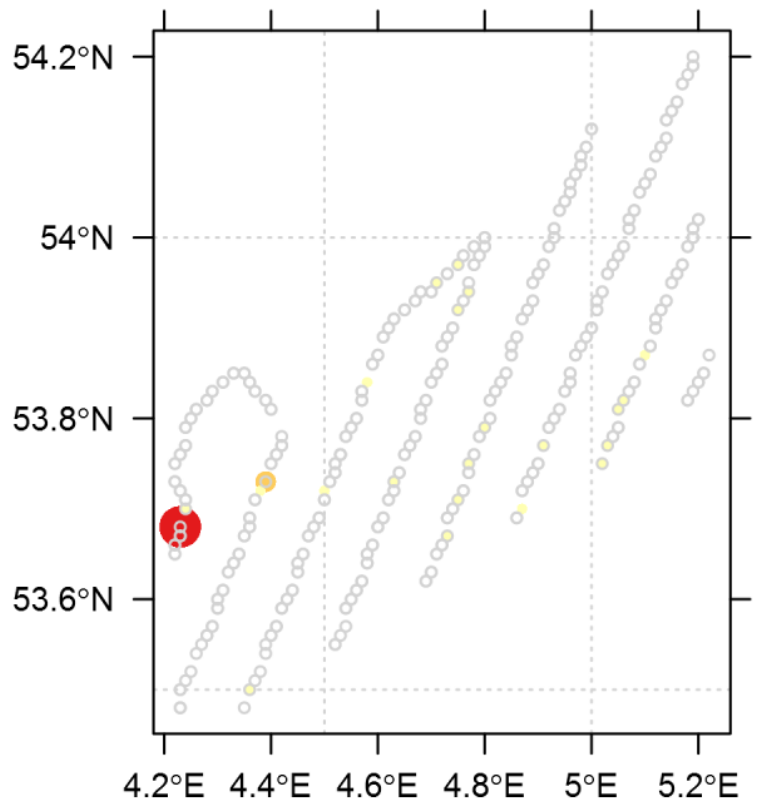

$$
\begin{array}{ll}
0 & >50 ;<=100 \\
>0 ;<=25 & >100 \\
>25 ;<=50 &
\end{array}
$$

Figuur 17. Verspreiding van Kleine Mantelmeeuw tijdens de survey op het Friese Front 24-25 juli 2017. Weergegeven zijn de gemiddelde aantallen per 5-mintelling.

\subsubsection{Grote Mantelmeeuw}

$\begin{array}{llll} & \text { jan-BB } & \text { mrt-FF } & \text { jul-FF } \\ \text { Aantal } & 1797 & 38 & 2\end{array}$

In tegenstelling tot Kleine Mantelmeeuw werden Grote Mantelmeeuwen vrijwel uitsluitend in de winter (januari en in mindere mate in maart) gezien. De aantallen in juli waren laag. In januari was de Grote Mantelmeeuw de talrijkste meeuwensoort op de Bruine Bank. De verspreiding was onregelmatig met hogere aantallen in het zuidelijk deel van het gebied, waar ook enkele viskotters actief waren. Op het Friese Front was de soort in maart schaars en waren de waarnemingen beperkt tot de oostrand van het studiegebied. De verspreiding van Grote Mantelmeeuwen werd sterk bepaald door menselijke activiteit; $80 \%$ was geassocieerd met viskotters $(n=1837)$. In januari overheersten volwassen vogels $(62 \%, n=306)$, In maart was het aandeel volwassen vogels gedaald naar $57 \%(n=35)$. In juli werden alleen nog twee onvolwassen vogels gezien. De verhouding tussen Grote en Kleine Mantelmeeuw was respectievelijk $112: 1$ in januari, $1: 1.5$ in maart en $1: 114$ in juli. 


\section{jan_Bruine_Bank Grote Mantelmeeuw}

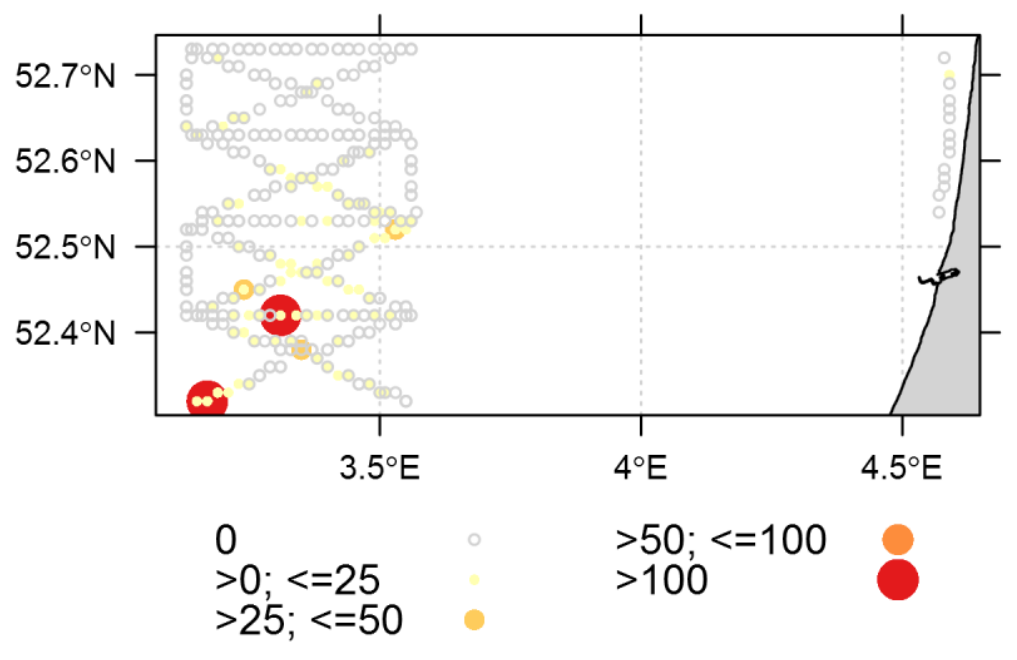

Figuur 18. Verspreiding van Grote Mantelmeeuw tijdens de survey op de Bruine Bank 23-26 januari 2017. Weergegeven zijn de gemiddelde aantallen per 5-mintelling.

\section{naart_Friese_Front Grote Mantelmeeun}

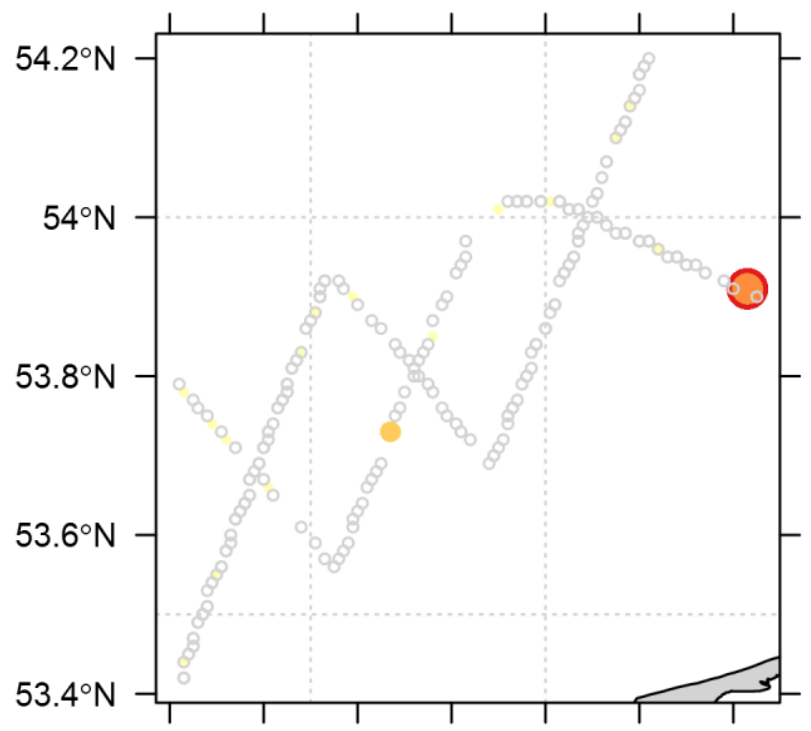

$4.2^{\circ} \mathrm{E} 4.4^{\circ} \mathrm{E} 4.6^{\circ} \mathrm{E} 4.8^{\circ} \mathrm{E} \quad 5^{\circ} \mathrm{E} \quad 5.2^{\circ} \mathrm{E} 5.4^{\circ} \mathrm{E}$

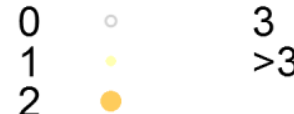

Figuur 19. Verspreiding van Grote Mantelmeeuw tijdens de survey op het Friese Front 1-2 maart 2017. Weergegeven zijn de gemiddelde aantallen per 5-mintelling. 


\section{juli_Friese_Front Grote Mantelmeeuw}

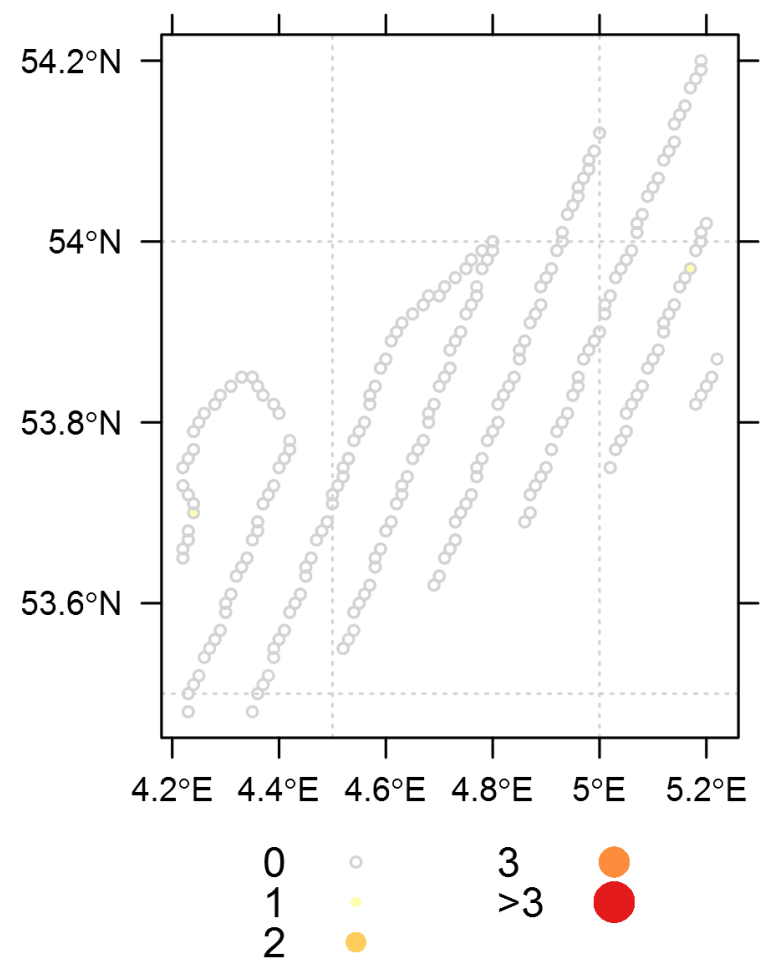

Figuur 20. Verspreiding van Grote Mantelmeeuw tijdens de survey op het Friese Front 24-25 juli 2017. Weergegeven zijn de gemiddelde aantallen per 5-mintelling

\subsubsection{Drieteenmeeuw}

$\begin{array}{llll} & \text { jan-BB } & \text { mrt-FF } & \text { jul-FF } \\ \text { Aantal } & 771 & 151 & 530\end{array}$

Drieteenmeeuwen werden tijdens alle surveys gezien. In maart waren de laagste aantallen Drieteenmeeuwen geteld. In januari werden de hoogste aantallen gezien (op de Bruine Bank), met een zwaartepunt in de zuidelijke helft van het gebied. Op het Friese Front werden Drieteenmeeuwen tijdens beide surveys onregelmatiger verspreid gezien. De verspreiding van Drieteenmeeuwen werd grotendeels bepaald door menselijke activiteiten. Een groot deel van de vogels was geassocieerd met een viskotter $(35 \%)$ of geassocieerd met een gas productie platform $(60 \%, n=1345)$.

Vermeldenswaard is de waarneming op 25 juli van kolonies Drieteenmeeuwen op twee platforms aan de zuidkant van het Friese Front. Aan de hand van foto's werden minstens 50 en 112 nesten geteld. Ook konden minstens 73 kuikens of juveniele vogels vastgesteld worden.

Het merendeel van de waargenomen Drieteenmeeuwen was adult, respectievelijk $82 \%(n=214)$ in januari, $84 \%$ ( $n=102)$ in maart en $81 \%$ in juli $(n=416)$. Met uitzondering van vier tweedejaarsvogels waren de overige vogels eerstejaars. 


\section{jan_Bruine_Bank Drieteenmeeuw}

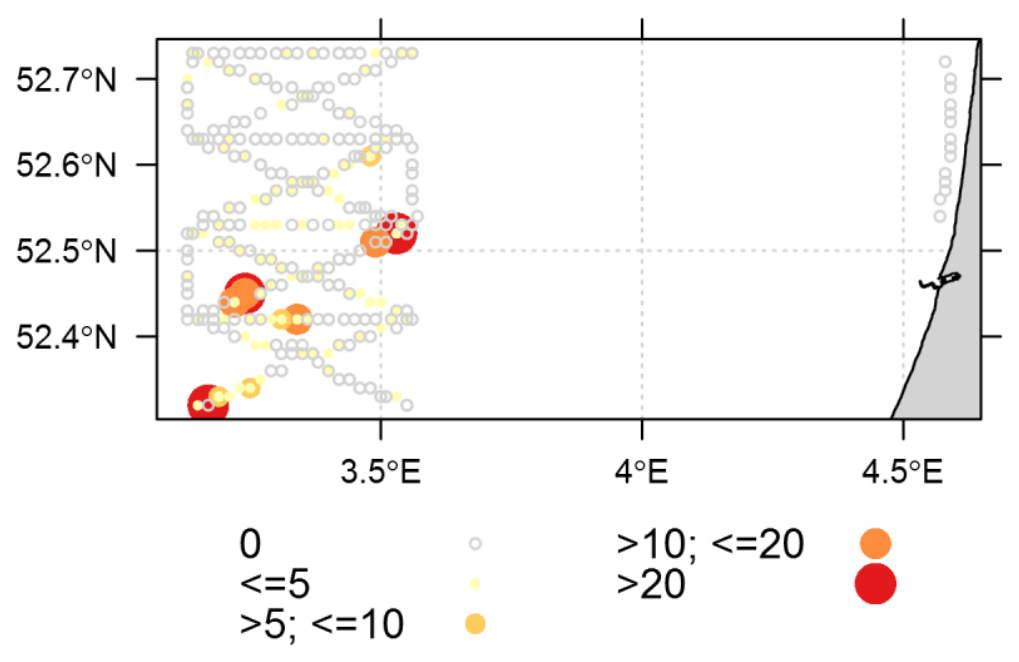

Figuur 21. Verspreiding van Drieteenmeeuw tijdens de survey op de Bruine Bank 23-26 januari 2017. Weergegeven zijn de gemiddelde aantallen per 5-mintelling.

\section{maart_Friese_Front Drieteenmeeuw}

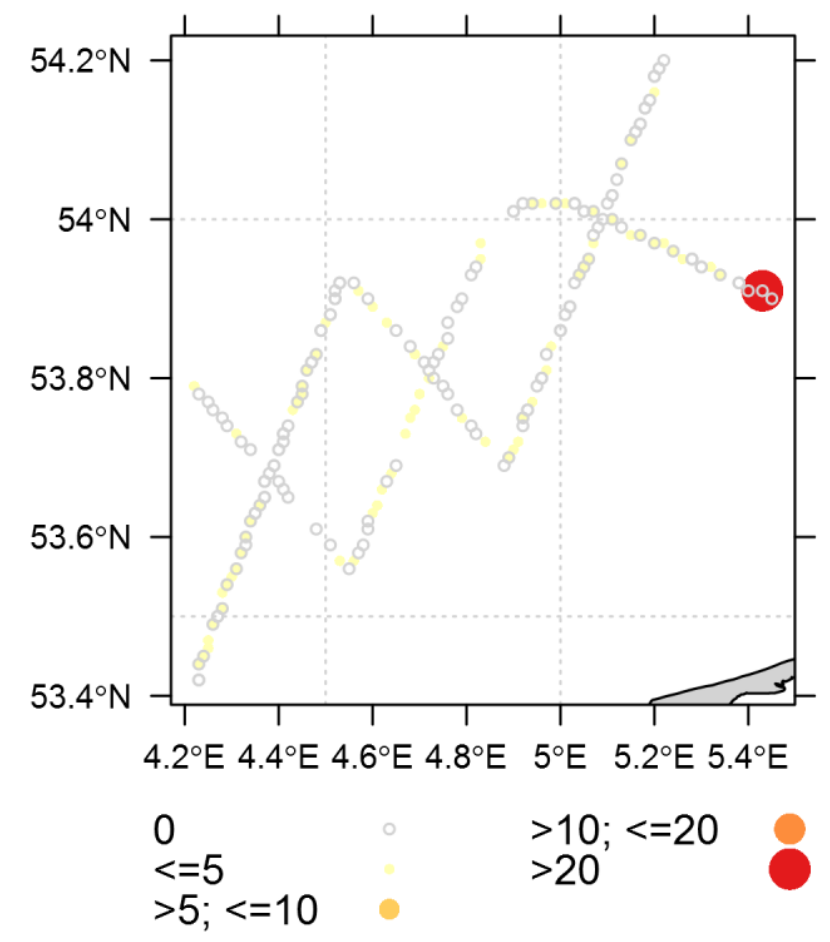

Figuur 22. Verspreiding van Drieteenmeeuw tijdens de survey op het Friese Front 1-2 maart 2017. Weergegeven zijn de gemiddelde aantallen per 5-mintelling. 


\section{juli_Friese_Front Drieteenmeeuw}

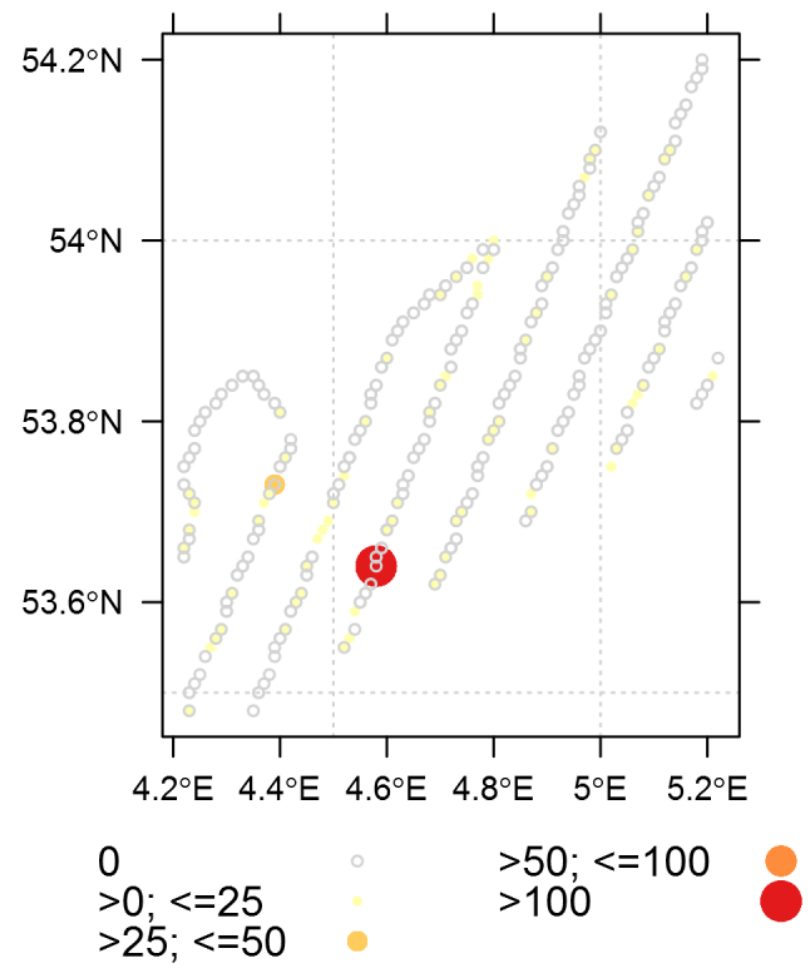

Figuur 23. Verspreiding van Drieteenmeeuw tijdens de survey op het Friese Front 24-25 juli 2017. Weergegeven zijn de gemiddelde aantallen per 5-mintelling

\subsubsection{Alk}

$\begin{array}{llll} & \text { jan-BB } & \text { mrt-FF } & \text { jul-FF } \\ \text { Aantal } & 435 & 70 & 1\end{array}$

Alken werden voornamelijk tijdens de eerste (mid-winter) survey op de Bruine Bank gezien. Op het Friese Front werden in maart nog redelijke aantallen gezien, maar in juli werd hier nog slechts één vogel gezien. In januari hadden Alken een ruime verspreiding op de Bruine Bank met een zwaartepunt in het noordwestelijk deel van het gebied. In het zuidoostelijk deel waren de dichtheden tijdens de survey laag, evenals dicht onder de kust. Op het Friese Front werden de meeste Alken in maart ten noorden van het front gezien, met name op de westelijke transecten. Ten zuiden van het front was de verspreiding onregelmatiger.

Het aandeel vogels in broedkleed steeg van $1 \%(n=526)$ in januari naar $29 \%(n=78)$ in maart. Op 20 individuen in overgangskleed na, waren de overige vogels allemaal in winterkleed. 


\section{jan_Bruine_Bank Alk}

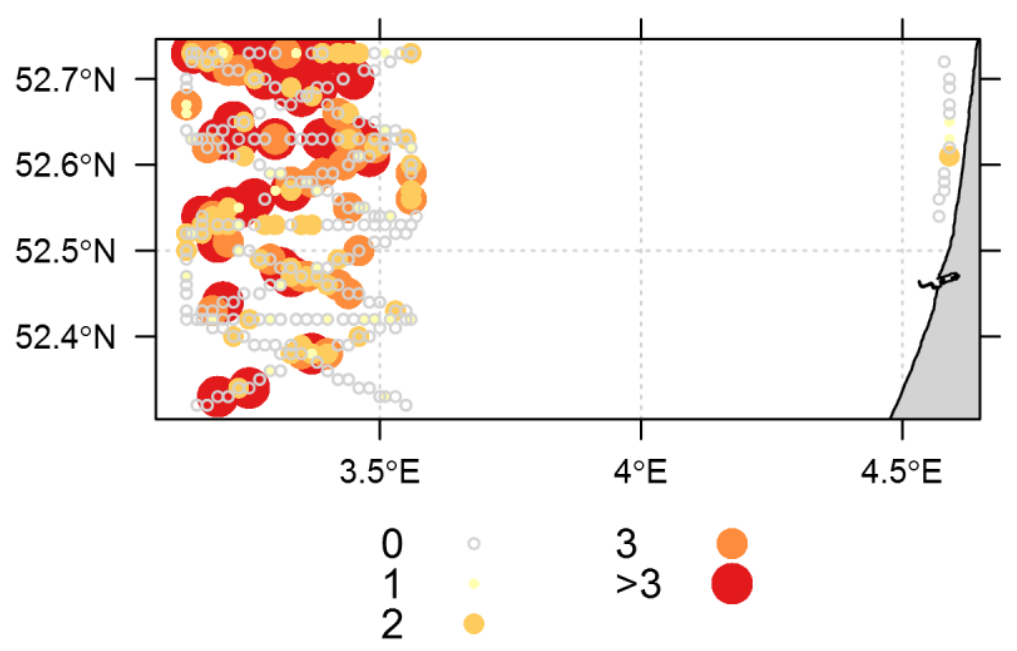

Figuur 24. Verspreiding van Alk tijdens de survey op de Bruine Bank 23-26 januari 2017. Weergegeven zijn de gemiddelde aantallen per 5-mintelling.

\section{maart_Friese_Front Alk}

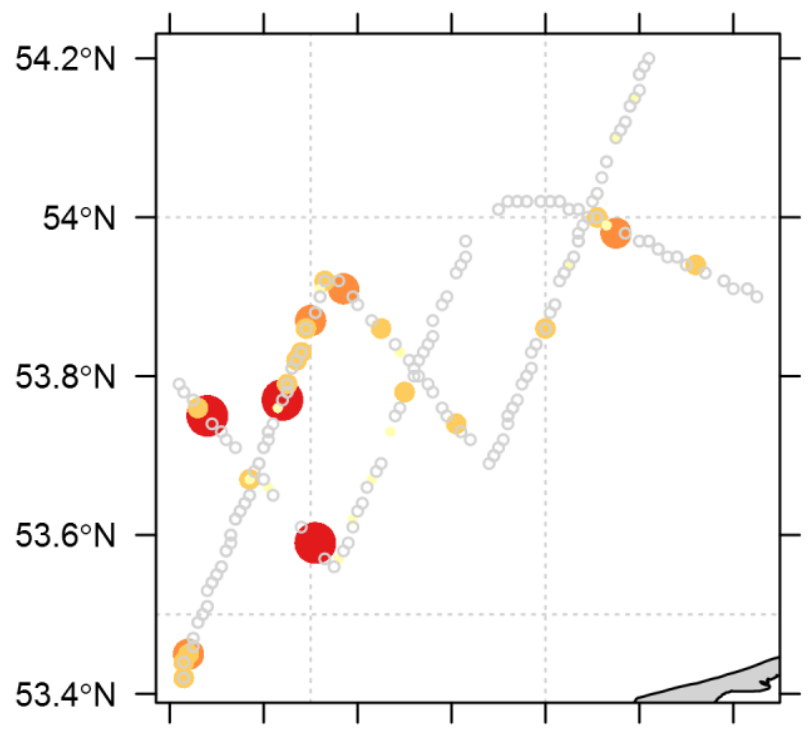

$4.2^{\circ} \mathrm{E} 4.4^{\circ} \mathrm{E} 4.6^{\circ} \mathrm{E} 4.8^{\circ} \mathrm{E} \quad 5^{\circ} \mathrm{E} \quad 5.2^{\circ} \mathrm{E} 5.4^{\circ} \mathrm{E}$

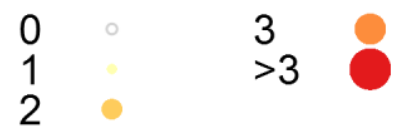

Figuur 25. Verspreiding van Alk tijdens de survey op het Friese Front 1-2 maart 2017. Weergegeven zijn de gemiddelde aantallen per 5-mintelling. 


\section{juli_Friese_Front Alk}
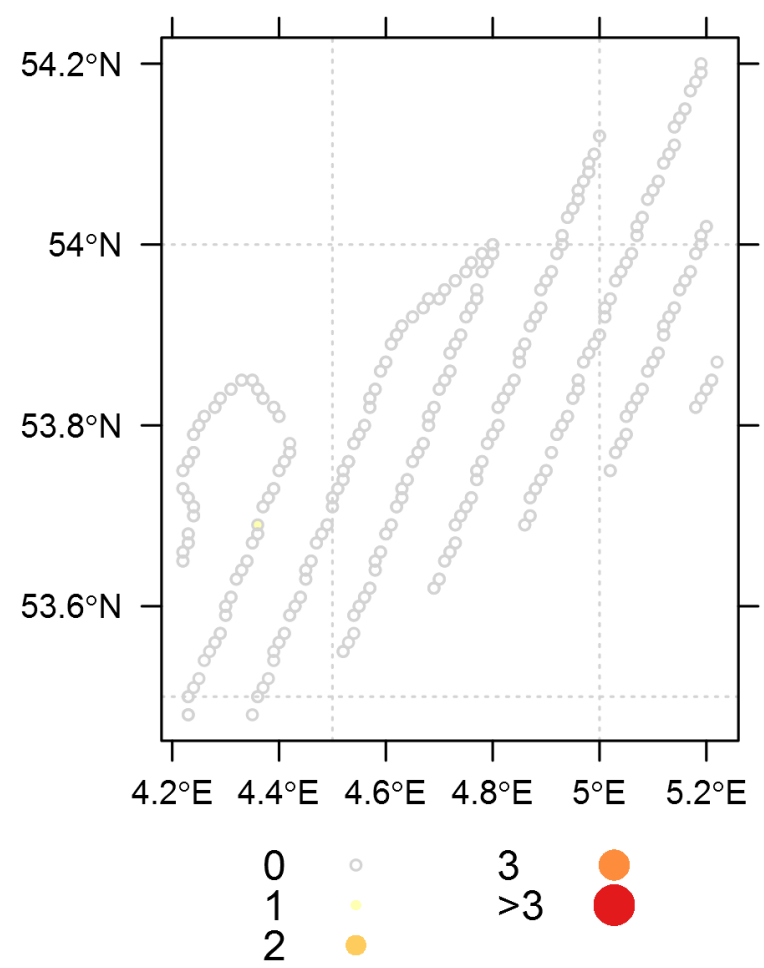

Figuur 26. Verspreiding van Alk tijdens de survey op het Friese Front 24-25 juli 2017. Weergegeven zijn de gemiddelde aantallen per 5-mintelling

\subsubsection{Zeekoet}

$\begin{array}{llll} & \text { jan-BB } & \text { mrt-FF } & \text { jul-FF } \\ \text { Aantal } & 1412 & 258 & 4725\end{array}$

Zeekoeten werden tijdens alle surveys in het hele onderzoeksgebied aangetroffen, met her en der hogere concentraties en elders lege gebieden. In maart en juli was Zeekoet op het Friese Front de talrijkste soort. In maart werden Zeekoeten met name in het westelijk deel van het gebied gezien. In juli was de verspreiding regelmatig. In januari waren Zeekoeten wijd verspreid over de Bruine Bank. In tegenstelling tot Alken werden Zeekoeten tijdens deze survey ook op een transect ver ten oosten van de Bruine Bank gezien (vlak onder de kust). Het aandeel vogels in broedkleed was het laagst in maart ( $25 \%, n=253$, op het Friese Front). In juli was het aandeel vogels in broedkleed op het Friese Front $64 \%(n=2552)$. Als de kuikens buiten beschouwing worden gelaten $(n=469)$ dan bedraagt het aandeel vogels in zomerkleed 79\%. In januari was dit aandeel op de Bruine Bank 73\% ( $n=$ 1043). In januari en maart was het gros van de overige vogels in winterkleed. In juli bedroeg het aandeel vogels in overgangskleed een vijfvoud van de winterkleedvogels.

De verhouding tussen Alken en Zeekoeten verschillende niet alleen per survey maar ook binnen een surveygebied (zie dagtotalen in de bijlage). Op de Bruine Bank in januari en op het Friese Front in maart was de verhouding Alk: Zeekoet respectievelijk 1: 3.2 en 1: 3.7. In juli werden of het Friese Front, op een Alk na, alleen maar Zeekoeten gezien (tabel 3). Het aandeel ongedetermineerde Alk/Zeekoeten $(\max <1 \%$ ) was verwaarloosbaar.

Tabel 3. Verhouding tussen aantallen Alken en Zeekoeten per survey.

$\begin{array}{llll} & \text { jan-BB } & \text { mrt-FF } & \text { jul-FF } \\ \text { Alk } & 435 & 70 & 1 \\ \text { Alk/Zeekoet } & 4 & 0 & 0 \\ \text { Zeekoet } & 1412 & 258 & 4725 \\ \text { Alk:Zeekoet } & 1: 3.2 & 1: 3.7 & 1: 4725.0\end{array}$




\section{jan_Bruine_Bank Zeekoet}

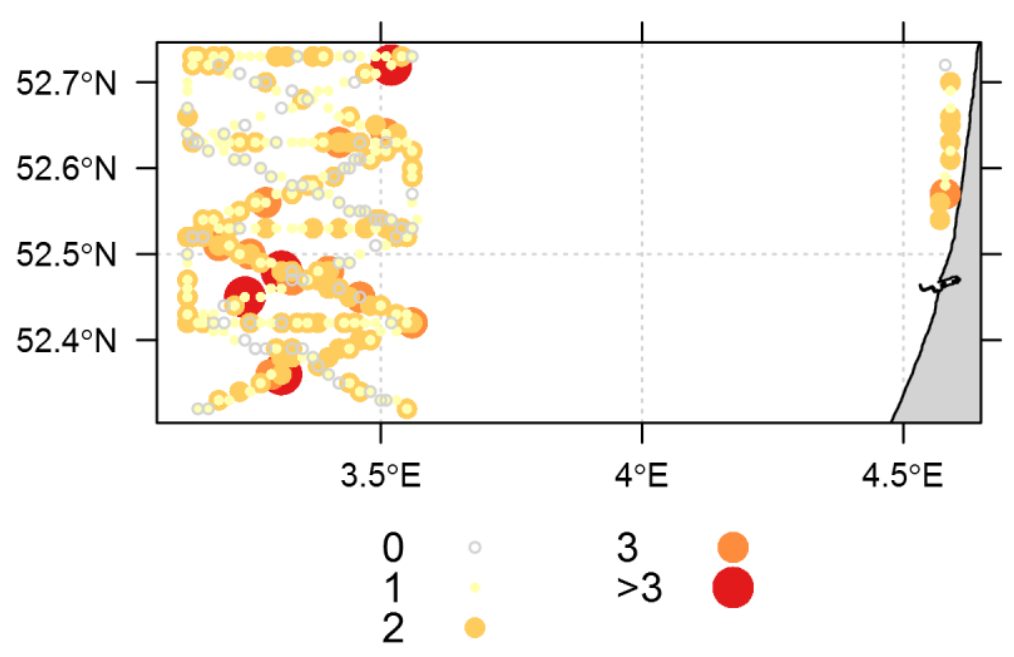

Figuur 27. Verspreiding van Zeekoet tijdens de survey op de Bruine Bank 23-26 januari 2017. Weergegeven zijn de gemiddelde aantallen per 5-mintelling.

\section{maart_Friese_Front Zeekoet}

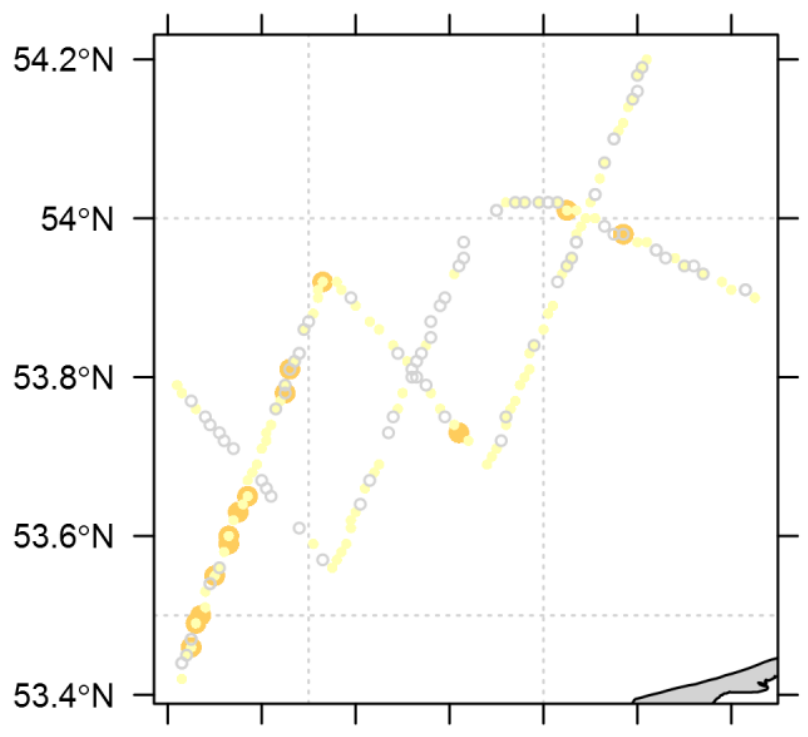

$4.2^{\circ} \mathrm{E} 4.4^{\circ} \mathrm{E} 4.6^{\circ} \mathrm{E} 4.8^{\circ} \mathrm{E} \quad 5^{\circ} \mathrm{E} 5.2^{\circ} \mathrm{E} 5.4^{\circ} \mathrm{E}$

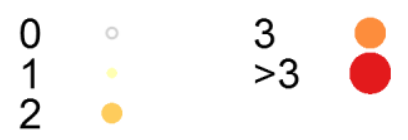

Figuur 28. Verspreiding van Zeekoet tijdens de survey op het Friese Front 1-2 maart 2017. Weergegeven zijn de gemiddelde aantallen per 5-mintelling. 


\section{juli_Friese_Front Zeekoet}
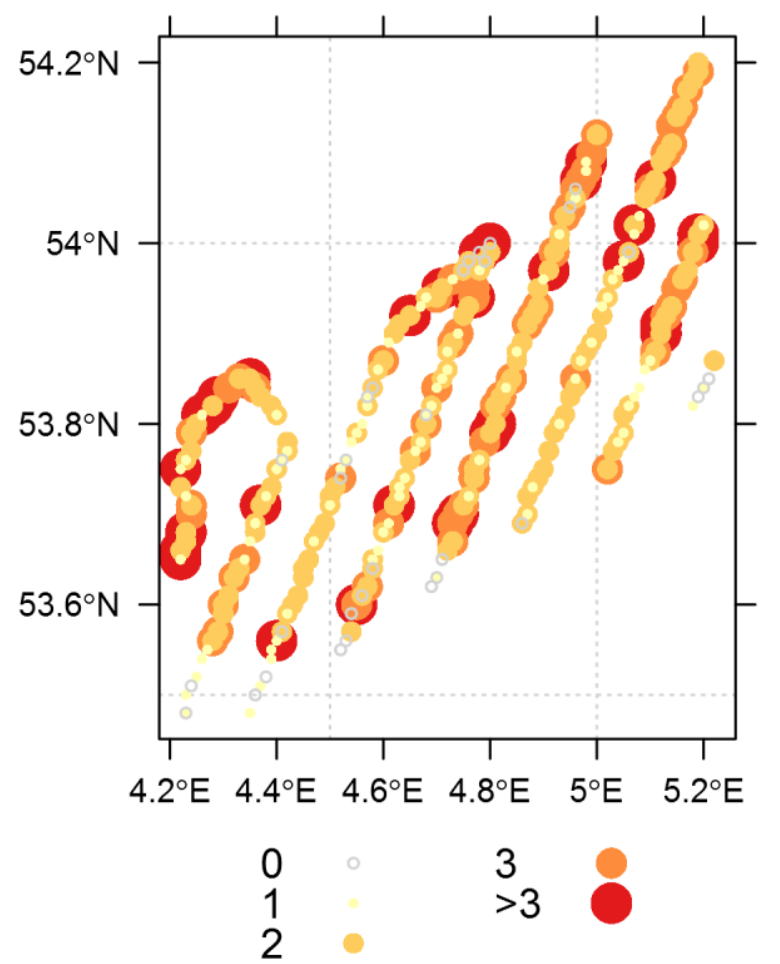

Figuur 29. Verspreiding van Zeekoet tijdens de survey op het Friese Front 24-25 juli 2017. Weergegeven zijn de gemiddelde aantallen per 5-mintelling.

\subsubsection{Bruinvis}

$\begin{array}{llll} & \text { jan-BB } & \text { mrt-FF } & \text { jul-FF } \\ \text { Aantal } & 126 & 20 & 54\end{array}$

Bruinvissen werden tijdens alle surveys gezien. De getelde aantallen en daarmee de ogenchijnlijke verspreiding waren sterk afhankelijk van de waarnemingsomstandigheden. Illustratief zijn de verschillen tussen de surveydagen op de Bruine Bank; op drie achtereenvolgende dagen zijn transecten onder verschillende weersomstandigheden over het gehele gebied geteld, maar de aantallen verschilden per dag. De lage aantallen op het Friese Front in maart zijn ongetwijfeld mede een gevolg van de slechtere waarnemingsomstandigheden. Tijdens deze survey was de zeestaat groter of gelijk aan 4 Beaufort.

De meeste Bruinvissen (83\%) werden als rustig zwemmend genoteerd; een kleiner aandeel $(6 \%, n=$ 200) werd als schip mijdend of als snel zwemmen $(5 \%, n=200)$ gekwalificeerd. Met name in januari werd een relatief groot aandeel als foeragerend genoteerd $(9 \%, n=200)$. 


\section{jan_Bruine_Bank Bruinvis}

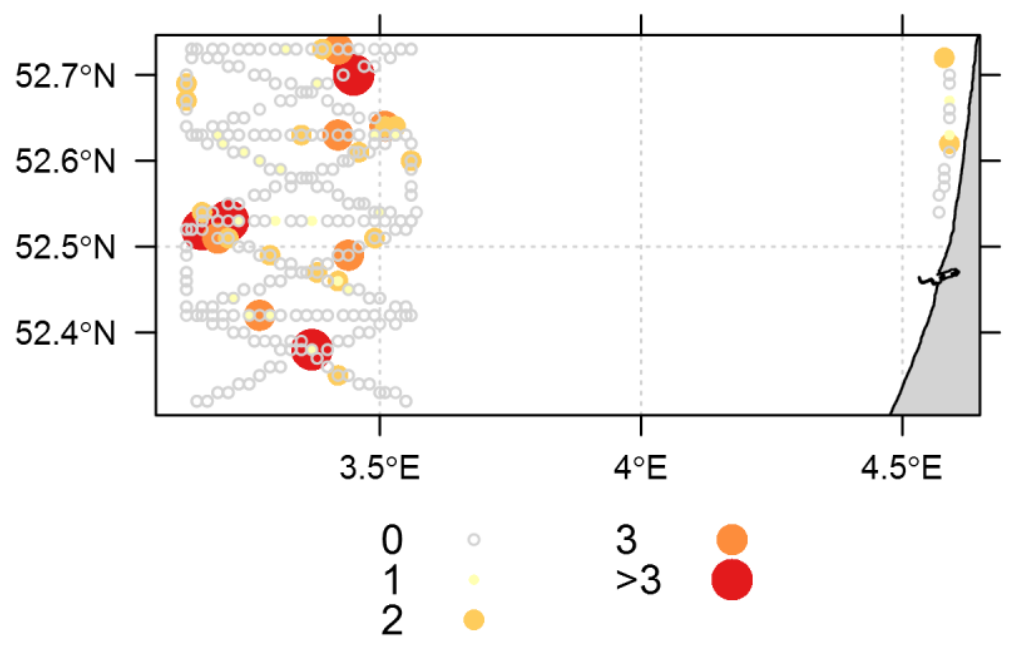

Figuur 30. Verspreiding van Bruinvis tijdens de survey op de Bruine Bank 23-26 januari 2017. Weergegeven zijn de gemiddelde aantallen per 5-mintelling.

\section{maart_Friese_Front Bruinvis}

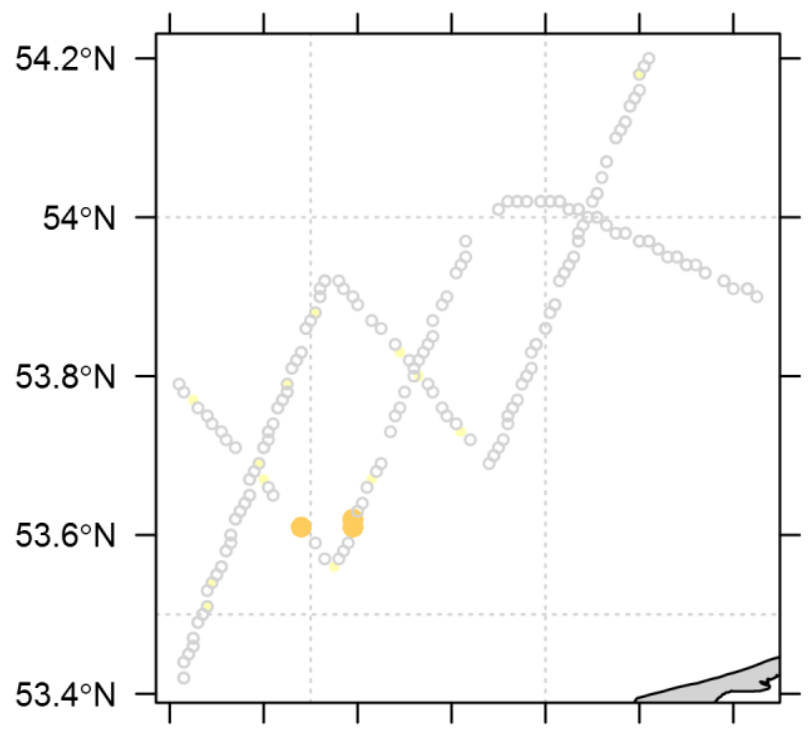

$4.2^{\circ} \mathrm{E} 4.4^{\circ} \mathrm{E} 4.6^{\circ} \mathrm{E} 4.8^{\circ} \mathrm{E} \quad 5^{\circ} \mathrm{E} \quad 5.2^{\circ} \mathrm{E} 5.4^{\circ} \mathrm{E}$

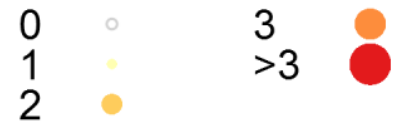

Figuur 31. Verspreiding van Bruinvis tijdens de survey op het Friese Front 1-2 maart 2017. Weergegeven zijn de gemiddelde aantallen per 5-mintelling. 


\section{juli_Friese_Front Bruinvis}

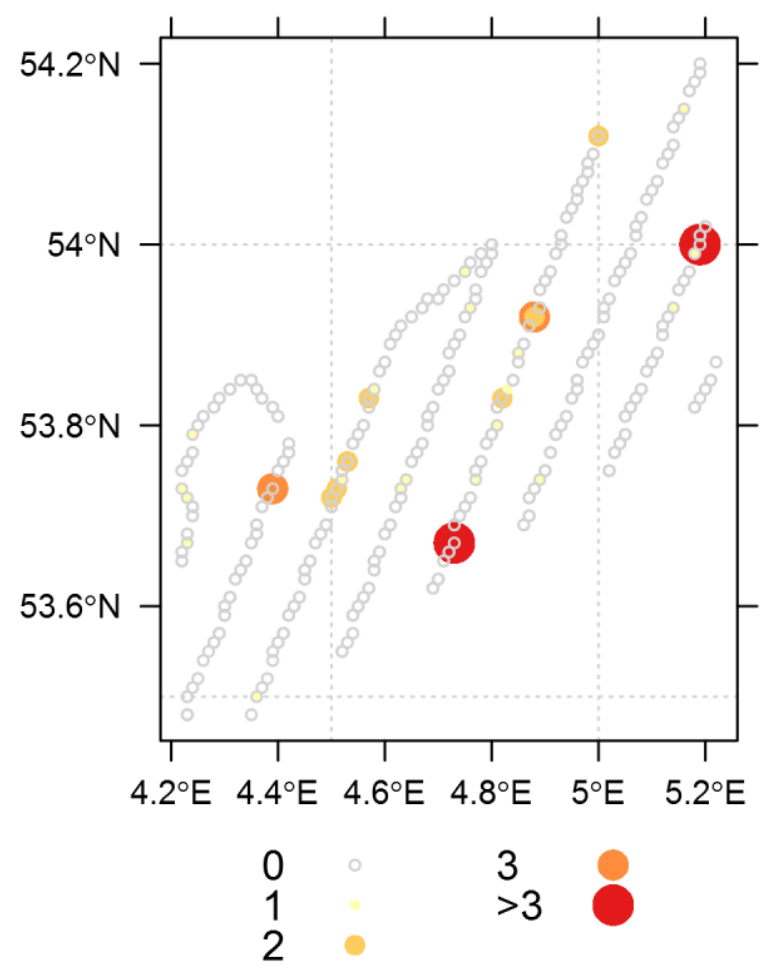

Figuur 32. Verspreiding van Bruinvis tijdens de survey op het Friese Front 24-25 juli 2017. Weergegeven zijn de gemiddelde aantallen per 5-mintelling

[nog iets over de overige zeezoogdieren]

[en overige zaken: ballonnen relatief opvallend talrijk in de zomer (FF)] 


\section{Conclusies en aanbevelingen}

In 2017 zijn drie surveys op het Friese Front en op de Bruine Bank uitgevoerd. Tijdens deze surveys behoorden Alken en Zeekoeten tot de talrijkste soorten. In juli werden de hoogste aantallen Zeekoeten op het Friese Front geteld, terwijl Alken hier nagenoeg ontbraken. De verhouding Alk: Zeekoet was op de Bruine Bank in januari en op het Friese Front in maart respectievelijk 1: 3.2 en 1: 3.7

Behalve van alkachtigen werden - zoals verwacht- aanvullende gegevens verzameld over de aantallen van potentieel kwalificerende N2000-soorten Grote Mantelmeeuw (met name jan-mrt) en Kleine Mantelmeeuw (met name jul). De aantallen van de potentieel kwalificerende N2000-soort Grote Jager waren tijdens alle 2017-surveys laag: dit is een soort die in Nederlandse wateren het talrijkst is tijdens de najaarstrek.

Opmerkelijk zijn de waarnemingen van twee kolonies Drieteenmeeuwen. Tijdens de julisurvey werden op twee platforms ten zuiden van op het Friese Front respectievelijk 50 en 112 nesten vastgesteld.

De getelde aantallen zijn niet hetzelfde als de aantallen vogels die totaal in het gebied aanwezig waren omdat het hier slechts een steekproef betreft. De omrekening naar totale aantallen aanwezig in de geïnventariseerde gebieden volgt in de eindrapportage. 


\section{Literatuur}

Bemmelen RSA van, Leopold MF \& Bos OG, 2012. Vogelwaarden van de Bruine Bank. Project Aanvullende Beschermde Gebieden (http://edepot.wur.nl/247418). Report C138/12, IMARES.

Camphuysen CJ \& Leopold MF 1994. Atlas of seabirds in the southern North Sea. IBN Research Report 94/6, NIOZ-Report 1994-8, Institute for Forestry and Nature Research, Dutch Seabird Group and Netherlands Institute for Sea Research, Texel.

Camphuysen C] \& Leopold MF, 2007. Drieteenmeeuw vestigt zich op meerdere platforms in Nederlandse wateren. Limosa 80: 153-156.

Camphuysen CJ \& Garthe S, 2004. Recording foraging seabirds at sea: standardised recording and coding of foraging behaviour and multi-species foraging associations. Atlantic Seabirds 6(1): 1-32.

Geelhoed SCV, Bos OG, Burggraaf D, Couperus AS \& Lagerveld S, 2014. Verklarende factoren voor de verspreiding van alken en zeekoeten op de Bruine Bank - Project Aanvullende Beschermde Gebieden Noordzee. IMARES Rapport C113.14.

Geelhoed SCV, \& Leopold MF, 2017. Cruiserapport scheepstellingen van zeevogels op het Friese Front en op de Bruine Bank, 2016. Wageningen Marine Research Wageningen UR (University \& Research centre), Wageningen Marine Research rapport C032/17.

Leopold M, Bemmelen R van \& Geelhoed S, 2009. We@Sea Friese Front cruise, 27 juli \& 2-6 augustus 2009- Een samenvatting van de vogel- en zeezoogdiertellingen. Rapport IMARES.

Leopold MF \& van der Wal JT, 2015. Kwalificerende en niet-kwalificerende vogelsoorten in het gebied "Bruine Bank". Vertrouwelijk IMARES Rapport C015/16.

Leopold MF, van der Wal JT \& Scholl M, 2015. Kwalificerende en niet-kwalificerende vogelsoorten in het gebied "Friese Front". IMARES Rapport C141/15.

Lindeboom H, Geurts van Kessel J \& Berkenbosch L, 2005. Gebieden met bijzondere ecologische waarden op het Nederlands Continentaal Plat. Rapport RIKZ/2005.008, Alterra Rapport nr. 1109.

Skov H, Durinck J, Leopold MF \& Tasker ML, 2007. A quantitative method for evaluating the importance of marine areas for conservation of birds. Biological Conservation 136:362-371.

Tasker ML, Jones PH, Dixon TJ \& Blake BF, 1984. Counting seabirds at sea from ships: a review of methods employed and a suggestion for a standardized approach. Auk 101: 567-577. 


\section{Kwaliteitsborging}

Wageningen Marine Research beschikt over een ISO 9001:2008 gecertificeerd kwaliteitsmanagementsysteem (certificaatnummer: 187378-2015-AQ-NLD-RvA). Dit certificaat is geldig tot 15 september 2018. De organisatie is gecertificeerd sinds 27 februari 2001. De certificering is uitgevoerd door DNV Certification B.V. 


\section{Verantwoording}

Rapport C035/18

Projectnummer: 4318100189

Dit rapport is met grote zorgvuldigheid tot stand gekomen. De wetenschappelijke kwaliteit is intern getoetst door een collega-onderzoeker en het verantwoordelijk lid van het managementteam van Wageningen Marine Research

$\begin{array}{ll}\text { Akkoord: } & \text { Erwin Winter } \\ \text { Onderzoeker }\end{array}$

Handtekening:

Datum: $\quad 3$ mei 2018

Akkoord: Drs. J. Asjes

Manager integratie

Handtekening:

Datum: 


\section{Bijlagen Aantallen waargenomen vogels en zeezoogdieren}

Aantallen waargenomen vogels en zeezoogdieren per dag, Bruine Bank 23-26 januari 2017.

\begin{tabular}{|c|c|c|c|c|c|c|}
\hline & & 23-jan & 24-jan & 25-jan & 26-jan & Totaal \\
\hline Tellingen zonder vogels & & 13 & 4 & 8 & & 25 \\
\hline Roodkeelduiker & Gavia stellata & 3 & 3 & & 16 & 22 \\
\hline Fuut & Podiceps cristatus & & & & 11 & 11 \\
\hline Noordse Stormvogel & Fulmarus glacialis & 70 & 143 & 97 & & 310 \\
\hline $\begin{array}{l}\text { Grote/Kuhls } \\
\text { Pijlstormvogel }\end{array}$ & P. gravis/C. diomedea & & & 1 & & 1 \\
\hline Vaal Stormvogeltje & Oceanodroma leucorhoa & & & 1 & & 1 \\
\hline Jan van Gent & Sula bassana & 501 & 195 & 206 & & 902 \\
\hline Aalscholver & Phalacrocorax carbo & 3 & & & 1201 & 1204 \\
\hline Kleine Rietgans & Anser brachyrhynchus & & & 9 & & 9 \\
\hline Kolgans & Anser albifrons & & & 55 & 85 & 140 \\
\hline Grauwe Gans & Anser anser & & & 61 & & 61 \\
\hline Brandgans & Branta leucopsis & & & 9 & 1 & 10 \\
\hline ongedeterm. gans & Anser/Branta spec. & & 1 & 578 & & 579 \\
\hline Smient & Anas penelope & & & 52 & 2 & 54 \\
\hline Krakeend & Anas strepera & & & 2 & & 2 \\
\hline Wilde Eend & Anas platyrhynchos & & & 7 & & 7 \\
\hline Zwarte Zee-eend & Melanitta nigra & & 22 & & 118 & 140 \\
\hline Grote Jager & Stercorarius skua & 2 & 3 & 1 & & 6 \\
\hline Dwergmeeuw & Larus minutus & & & 2 & & 2 \\
\hline Kokmeeuw & Larus ridibundus & & & 3 & & 3 \\
\hline Stormmeeuw & Larus canus & 191 & 94 & 10 & 78 & 373 \\
\hline Kleine Mantelmeeuw & Larus fuscus & 13 & 3 & & & 16 \\
\hline Zilvermeeuw & Larus argentatus & 77 & 28 & 4 & 9 & 118 \\
\hline Geelpootmeeuw & Larus michahellis & 2 & & & & 2 \\
\hline Grote Burgemeester & Larus hyperboreus & 1 & 2 & & & 3 \\
\hline Grote Mantelmeeuw & Larus marinus & 654 & 583 & 559 & 1 & 1797 \\
\hline Drieteenmeeuw & Rissa tridactyla & 250 & 411 & 110 & & 771 \\
\hline ongedeterm. meeuw & Larus spec. & 750 & & & 400 & 1150 \\
\hline Zeekoet & Uria aalge & 228 & 567 & 531 & 86 & 1412 \\
\hline Alk / Zeekoet & Alca torda / Uria aalge & 2 & 2 & & & 4 \\
\hline Alk & Alca torda & 95 & 336 & & 4 & 435 \\
\hline Papegaaiduiker & Fratercula arctica & 1 & & & & 1 \\
\hline Witsnuitdolfijn & $\begin{array}{l}\text { Lagenorhynchus } \\
\text { albirostris }\end{array}$ & 10 & 6 & & & 16 \\
\hline Bultrug & Megaptera novaeangliae & & & & 1 & 1 \\
\hline Bruinvis & Phocoena phocoena & 26 & 43 & 47 & 10 & 126 \\
\hline ongedeterm. zeehond & unidentified pinniped & & & & 1 & 1 \\
\hline Grijze Zeehond & Halichoerus grypus & & 8 & & & 8 \\
\hline Gewone Zeehond & Phoca vitulina & & & & 1 & 1 \\
\hline
\end{tabular}




\begin{tabular}{llllll}
\hline & 23 -jan & 24-jan & 25-jan & 26-jan & Totaal \\
\hline staand want & 2 & & 2 \\
ballon & 4 & & & 4 \\
\hline & 2892 & 2460 & 2306 & 2025 & 9683 \\
\hline
\end{tabular}

Aantallen waargenomen vogels en zeezoogdieren per dag, Friese Front 1 -2 maart 2017.

\begin{tabular}{|c|c|c|c|c|}
\hline & & $1 \mathrm{mrt}$ & $2 \mathrm{mrt}$ & Totaal \\
\hline Tellingen zonder vogels & Counts with no birds & 38 & 25 & 63 \\
\hline Roodkeelduiker & Gavia stellata & 2 & & 2 \\
\hline IJsduiker & Gavia immer & 1 & & 1 \\
\hline Noordse Stormvogel & Fulmarus glacialis & 8 & 8 & 16 \\
\hline Jan van Gent & Sula bassana & 15 & 44 & 59 \\
\hline Zwarte Zee-eend & Melanitta nigra & 2 & & 2 \\
\hline Kokmeeuw & Larus ridibundus & 1 & & 1 \\
\hline Stormmeeuw & Larus canus & 4 & 2 & 6 \\
\hline Kleine Mantelmeeuw & Larus fuscus & 1 & 56 & 57 \\
\hline Zilvermeeuw & Larus argentatus & 1 & & 1 \\
\hline Grote Mantelmeeuw & Larus marinus & 7 & 31 & 38 \\
\hline Drieteenmeeuw & Rissa tridactyla & 68 & 83 & 151 \\
\hline Zeekoet & Uria aalge & 192 & 66 & 258 \\
\hline Alk & Alca torda & 69 & 1 & 70 \\
\hline Papegaaiduiker & Fratercula arctica & 1 & 36 & 37 \\
\hline Graspieper & Anthus pratensis & 1 & & 1 \\
\hline Bruinvis & Phocoena phocoena & 9 & 11 & 20 \\
\hline Gewone Zeehond & Phoca vitulina & & 2 & 2 \\
\hline ballon & & 4 & & 4 \\
\hline \multirow[t]{2}{*}{ folie-ballon } & & 3 & & 3 \\
\hline & & 427 & 365 & 792 \\
\hline
\end{tabular}

Aantallen waargenomen vogels en zeezoogdieren per dag, Friese Front 24-25 juli 2017.

\begin{tabular}{lllll}
\hline & & $24-j u l$ & $25-j u l$ & Totaal \\
\hline Tellingen zonder vogels & & 5 & 15 & 20 \\
Noordse Stormvogel & Fulmarus glacialis & 65 & 142 & 207 \\
Noordse Pijlstormvogel & Puffinus puffinus & 1 & & 1 \\
Jan van Gent & Sula bassana & 474 & 114 & 588 \\
Zwarte Zee-eend & Melanitta nigra & 6 & 52 & 58 \\
Bonte Strandloper & Calidris alpina & 2 & & 2 \\
Kleine Jager & Stercorarius parasiticus & & 1 & 1 \\
Grote Jager & Stercorarius skua & & 3 & 3 \\
Zwartkopmeeuw & Larus melanocephalus & & 1 & 1 \\
Dwergmeeuw & Larus minutus & & 10 & 10 \\
Kokmeeuw & Larus ridibundus & 1 & 2 & 3 \\
Stormmeeuw & Larus canus & 2 & 1 & 3 \\
Kleine Mantelmeeuw & Larus fuscus & 19 & 209 & 228 \\
Zilvermeeuw & Larus argentatus & 1 & & 1
\end{tabular}




\begin{tabular}{lllll}
\hline & & $24-j u l$ & 25 -jul & Totaal \\
\hline Grote Mantelmeeuw & Larus marinus & 1 & 1 & 2 \\
Drieteenmeeuw & Rissa tridactyla & 82 & 448 & 530 \\
Visdief & Sterna hirundo & 25 & 55 & 80 \\
Visdief / Noordse Stern & S. hirundo / S. paradisaea & 1 & 25 & 26 \\
Dwergstern & Sterna albifrons & 1 & & 1 \\
Zeekoet & Uria aalge & 2561 & 2164 & 4725 \\
Alk & Alca torda & & 1 & 1 \\
Bruinvis & Phocoena phocoena & 31 & 23 & 54 \\
ongedeterm. zeehond & unidentified pinniped & 1 & & 1 \\
Grijze Zeehond & Halichoerus grypus & 1 & 2 & 3 \\
ballon & & 15 & 6 & 21 \\
folie-ballon & & 3 & 1 & 4 \\
\hline & & 3298 & 3276 & 6574 \\
\hline
\end{tabular}


Wageningen Marine Research

T: +31 (0)317480900

E: marine-research@wur.nl

www.wur.nl/marine-research

Visitors address

- Ankerpark 271781 AG Den Helder

- Korringaweg 7, 4401 NT Yerseke

- Haringkade 1, 1976 CP IJmuiden
Wageningen Marine Research is the Netherlands research institute established to provide the scientific support that is essential for developing policies and innovation in respect of the marine environment, fishery activities, aquaculture and the maritime sector.

Wageningen University \& Research is specialised in the domain of healthy food and living environment.

The Wageningen Marine Research vision:

'To explore the potential of marine nature to improve the quality of life.'

\section{The Wageningen Marine Research mission}

- To conduct research with the aim of acquiring knowledge and offering advice on the sustainable management and use of marine and coastal areas.

- Wageningen Marine Research is an independent, leading scientific research institute.

Wageningen Marine Research is part of the international knowledge organisation Wageningen UR (University \& Research centre). Within Wageningen UR, nine specialised research institutes of Stichting Wageningen Research (a Foundation) have joined forces with Wageningen University to help answer the most important questions in the domain of healthy food and living environment. 